\title{
استخدام معلمي العلوم بالمرحلة الإبتدائية للتقويم القائم على الأداي وعلاقته ببعض مخرجات التعلم لدى تلاميذهم
}

\section{مروة محمد حافظ الشهيني صقر}

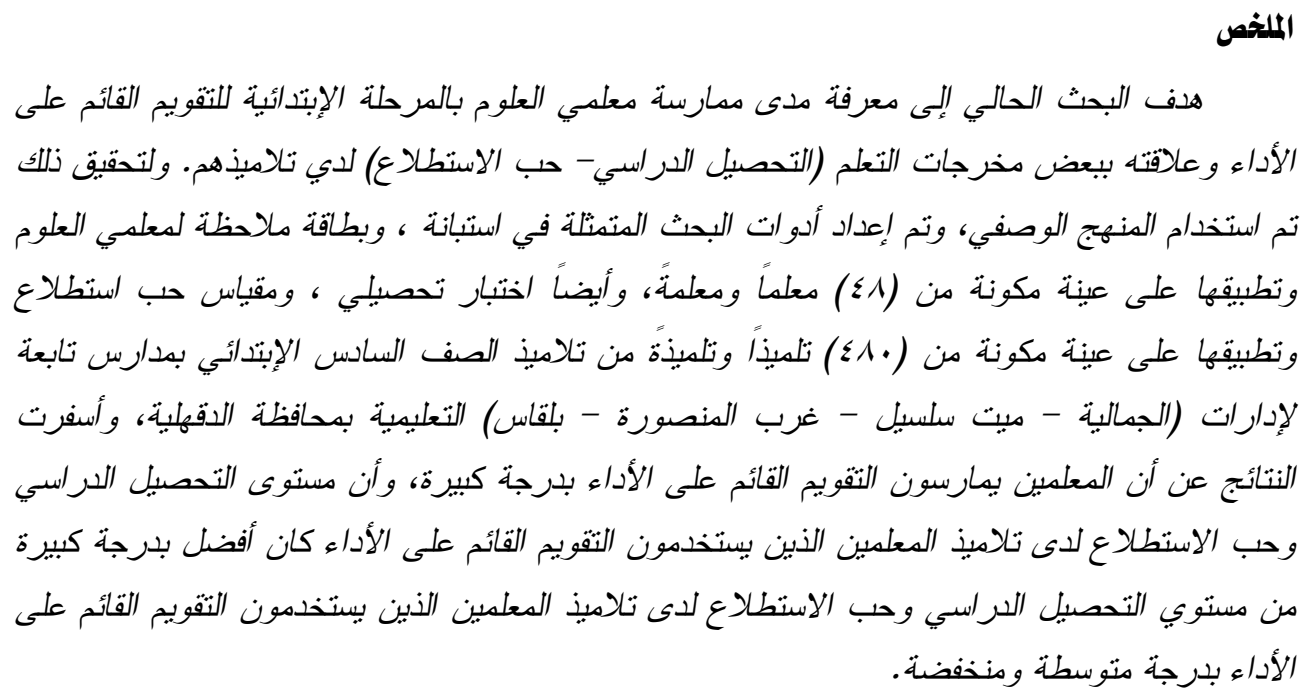

\section{Abstract:}

The aim of the current research is to know the extent of the use of the primary stage science teachers to performance-based-assessment and its relationship with some of their students' learning outcomes (academic achievement - curiosity). To achieve that, the descriptive method was used, and the research tools of a questionnaire and a note for science teachers were prepared, these tools were applied on a sample of (48) teachers, as well as an achievement test, a measure of curiosity were applied to a sample of (480) students. The sixth primary schools in the departments of (Elgamaliya - Mitt Salsil - West Mansoura - Belqas) educational Dakahlia Governorate, The results showed that teachers practiced performance-based assessment to a large extent, and that the level of academic achievement and curiosity of students of teachers using the performance-based assessment was significantly better than the level of educational achievement and curiosity of students of teachers using the performance-based assessment medium and low. 


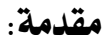

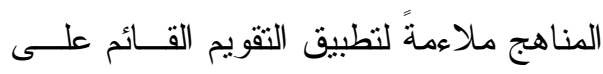

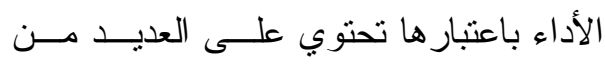

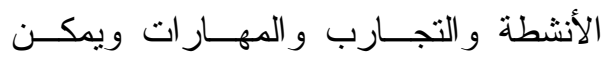
استخدام أكثر من مهمة لتحقيق هدف معين. ولتحقيق الأهداف التربوية المنـشـودة فإن ذلك يتطلب تغيراً فى المفاهيم التربويــة؛

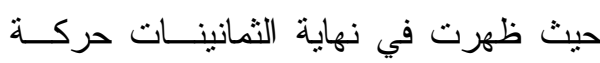
إصلاح جديدة تعتمد علــى التقــــيم البــديل والذى يعتمد على الثقويم القائم علــى الأداء

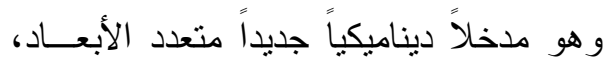

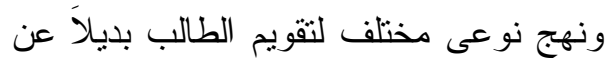
المنهج الإستاتيكي التقليدي أحادي البعد الذى نوع لطي يركز على جوانب معرفية بسيطة، وقد نــال

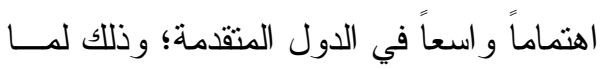
أظهرته الكثير من الدراسات عـن إمكانيــة

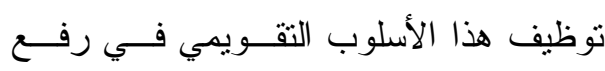

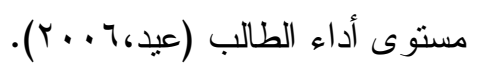

وقد كانت عمليات الاصلاح التربوي تُركز قديماً على المدخلات التزبوية، ولكـن الت

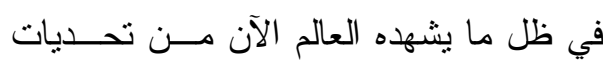

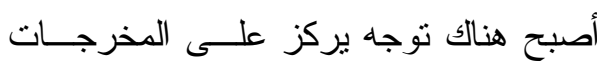

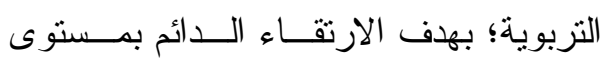
التعليم، و الاطمئنان على تحقيق رؤية رسالة المؤسسة التعليمية، و اصدار الحكم على مـــا

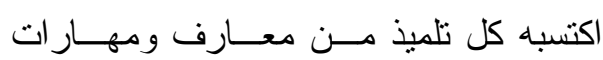

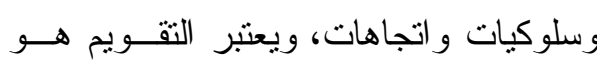

تتطلب العمليـــة التعليميـــة مو اكبـــة

التطور ات و المستجدات التـي تحــدث فـي لــي

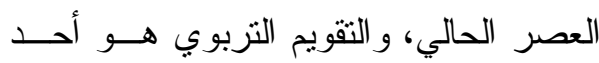
المكونات الأساسية في العمليــة التعليميـــة ؛ بحيث يُؤثر ويتأثر بكل مكون من مكوناتها ،

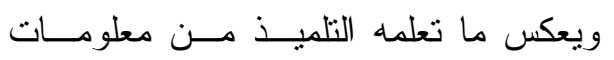

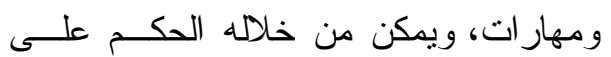

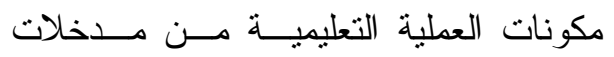

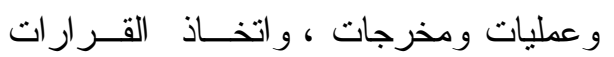

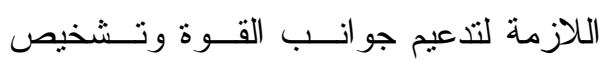
و علاج جو انسب الــضعف فــي مــدخلاتها

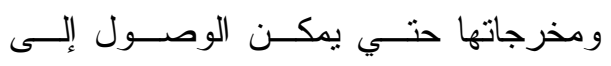
مخرجات مناسبة تُرضي الجميع. وتهذف مادة العلــوم إلـــى اكتــساب

الاهتمامات و الميول العلمية منل حب القر اءة العلمية و الالمام بالحقائق و المفاهيم العلميـــة بصورة وظيفية و اكتساب مهـار ات علميــة

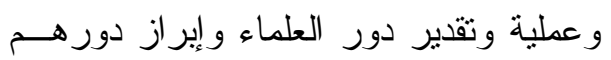

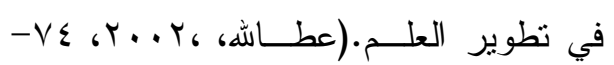
Vo)* و وقد تطورت أساليب التقويم باعتبار ها جز ءاً لا يتجز أ من المنظومة التعليمية ، وينت من خلاله تحديد مدى تحقيق أهداف العمليــة

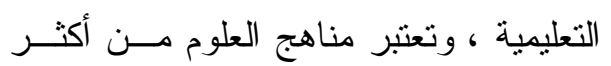
* يتم التوثيق في البحث وفقاً لنظام APA (الاسم الأخير،سنة النشر،رقم الصفحة) 
يعد مناسباً في ظل الانفجار المعرفي الــذي يشهده عالمنا المعاصر ؛ فالمعلومات لم تعـد لمديد محدودة بل لانهائية، و هذا بتطلب طرق ذاتية

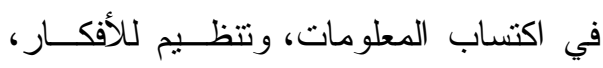
وتواصل مع الآخرين، وهذا يتطلب تغييــر

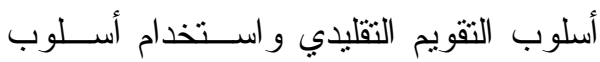
التقويم القائم على الأداء

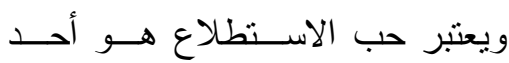

الاتجاهات التي تثير البحث وندفع المتعلمين إلي مزيد من النشاط و التعلم فتزداد رغباتهم في المعرفة و الفهــم لكتيــر مــن الأثـــياء و الأحداث و الظو اهر من حولهم في البيئـة، وهو من الاتجاهات التي يمكن تتميتها؛ لذلك

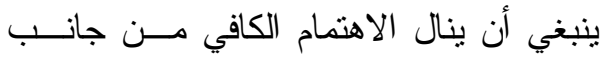
القائمين على العملية التعليمية ؛ وذلك لأنــهـ رغبة التلميذ للمعرفة و الفهم عنـــما يواجـهـ

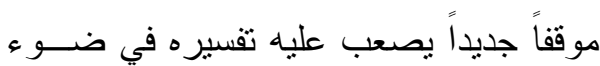

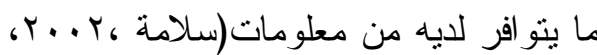

$$
.(7 .-09
$$

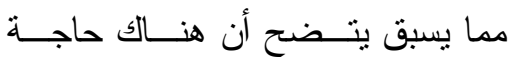

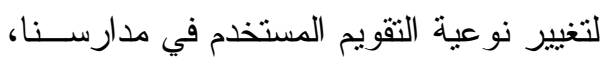

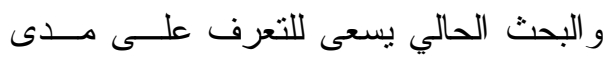
ممارسة معلمي علــوم المرحلـــة الإبتدائيـــة

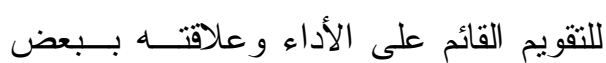
مخرجات التعلم لدى تلاميذهم وهي التحصيل

$$
\text { الدر اسي وحب الاسنطلاع. }
$$

الوسيلة للتعرف على مدى تحقيــق أهــــاف التعلم، ولذلك ينبغي استخدام أسلوب تقــــيم

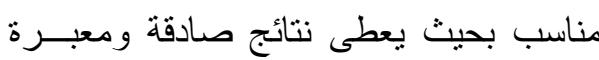

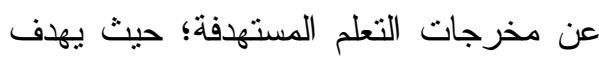
هذا البحث إلى مر اقبة مدى تقدم التلاميذ في العملية التعليمية و المساءلة التزبوية للمعلمين عن مدى تحقق النواتج التعليمية بما يــضمن تحسين عملية التعلم.

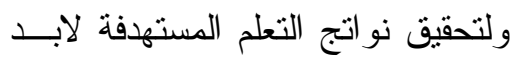
من أن يكون التقويم المستخدم يقدم صــورة

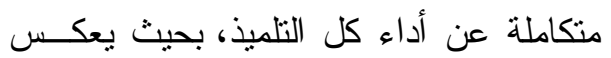
الأداء الفعلي؛ وبالنالي نحصل علـى نتــائج صادقة ومعبرة؛ و وعلى الرغم من ذلك فــإن

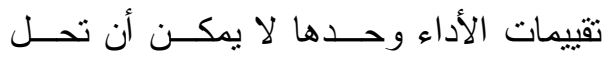
مشكلاتتا التعليمية، ولكنها يمكـن أن تكــــن النه خطوة أولى في إعادة التفكير فــي الطريقــة

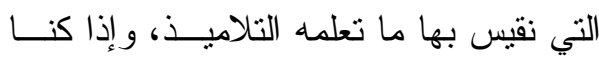
نتطلع إلى تحسين أدائهم؛ فندن بحاجة إلـى لـى

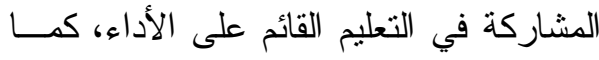

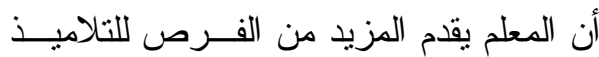

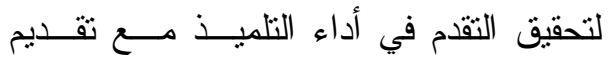
مساعدة مباشرة وذات مغزى. ( Harnisch) ,2015, 266-268 ويتم التعرف على مدى تحقق أهداف التعلم من خلال التحصيل الدراسي، وقد كان المفهوم التقليــدي للاختبــــار ات التحــــيلية متمنل في حفظ المعلومات و استرجاعها لـــ 
على الأداء وحــب الاســنطلاع منهـــا

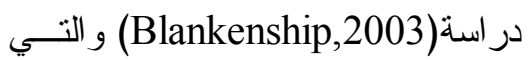

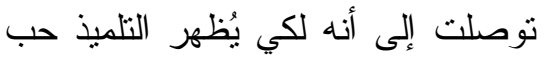
الاسنطلاع داخل الفصل لابد أن يشارك لئه

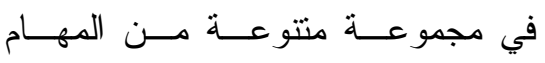
و الأنشطة.

r. كما أن القانون الفيدر الي يسمح بتطوير

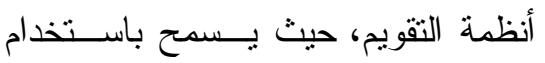

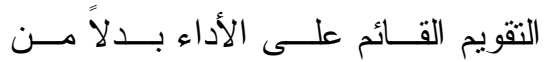

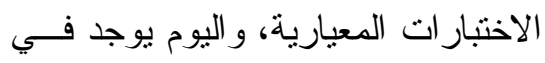

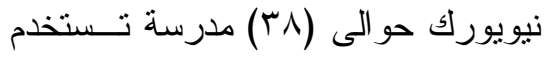

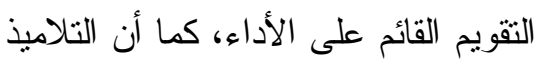
يشاركون في القر اعة و الكتابة و التحليــل و المناقثنة في الفصل الدر اســي بــشكل و اسع النطاق، وذللك لبناء مهام التقــــيم

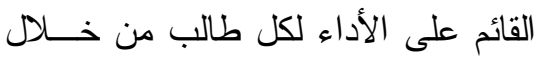
القيام بكتابة مقال تحليلي في الأدب ، أو لادئ لول ورقة بحث في الدراسات الاجتماعية، أو لو لون

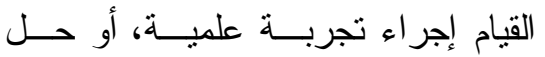

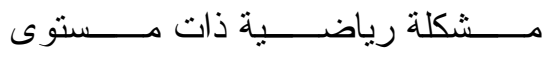

أعلى.) (Barlowe \& Cook,2016)

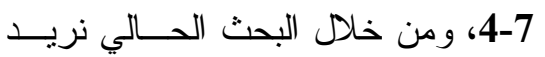
معرفة مدى استخدام المعلمـين لمهــــام الأداء منل أسئلة المقال و الكتابة و التعبير الثفوي و العروض العملية و التجــارب و الأداءات العملية و اليدوية داخل الفصل ولن ولن

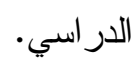

\section{الاحساس بالشكلة:}

يرجع إجر اء هذه الدر اسة إلي عدة أسباب:

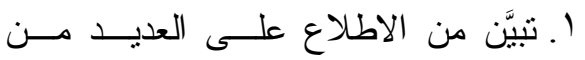
الدر اســـات الــسابقة مثتـلـل در اســـــة

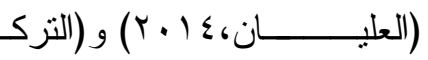

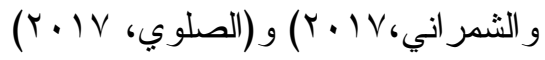

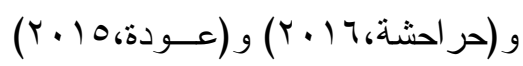

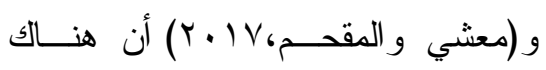
نسب متفاوتة في ممارسة معلمي العلوم

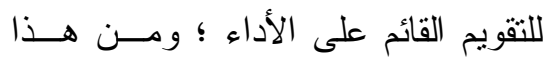
المنطلق يسعى البحث الحالي للتعـرف الته

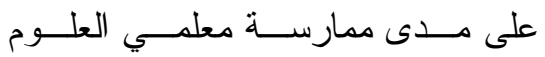

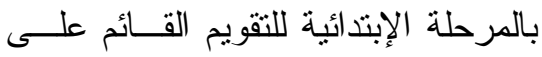
الأداء ؛ وذللك لأن التقويم الحقيقي يقــدم صورة صادقة وشاملة عن أداء التلاميذ مما يؤدي إلى التعرف على مدى تحقيق

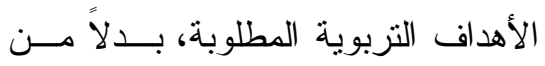

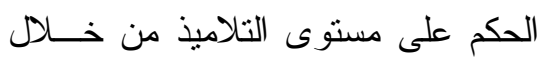

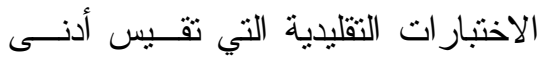
مستويات المعرفة وهي التذكر، كما أن

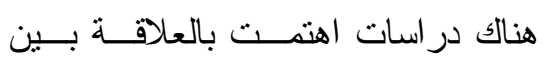

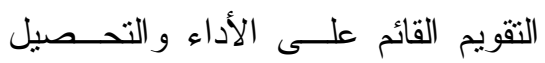

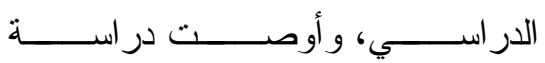

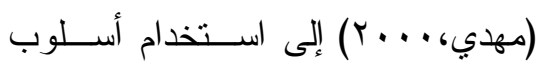
تقويم الأداء الكتابي في الحصة الدراسية

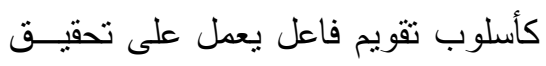
الأهداف، وهناك عدد قليل من الدر اسات التي تتاولت العلاقة بين التقــــيم القـائم 


$$
\begin{aligned}
& \text { 0) إلي أي مدي توجد علاقة إرنباطية بين } \\
& \text { في ضوء ما سبق، فإن البحث الحالي }
\end{aligned}
$$

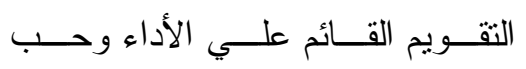

$$
\begin{aligned}
& \text { الاستطلاع لدى تلاميذ الصف السادس ولم الاد }
\end{aligned}
$$

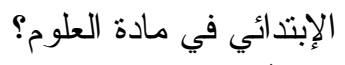

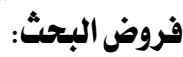

$$
\begin{aligned}
& \text { تمثلت فروض البحث فيما يلى: }
\end{aligned}
$$

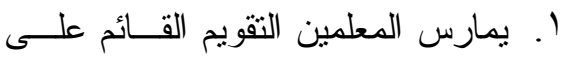

$$
\begin{aligned}
& \text { الأداء بدرجة كبيرة. } \\
& \text { r. مستوى التحصيل الدراسي لدى تلاميذ } \\
& \text { معلمي العلوم الذين يمارسون الثقــويم }
\end{aligned}
$$

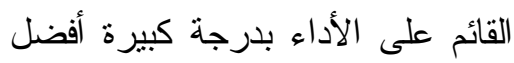

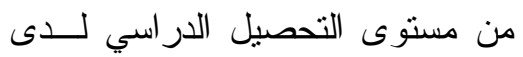

$$
\begin{aligned}
& \text { تلاميذ معلمي العلوم الذين يمارســون }
\end{aligned}
$$

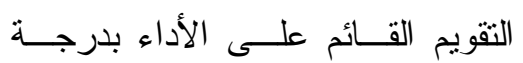

$$
\begin{aligned}
& \text { متوسطة ومنخفضة. } \\
& \text { r. . حب الاستطلاع لدى تلاميــذ معلمــي } \\
& \text { العلوم الذين يمارسون التقويم القــائم } \\
& \text { على الأداء بدرجة كبيرة أفضل مـنـ }
\end{aligned}
$$

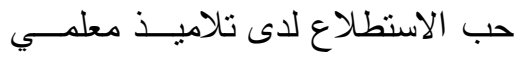

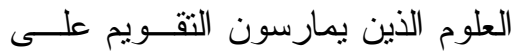

$$
\begin{aligned}
& \text { الأداء بدرجة متوسطة ومنخفضة. } \\
& \text { ع. توجد علاقة ارتباطية بين التقويم القائم }
\end{aligned}
$$

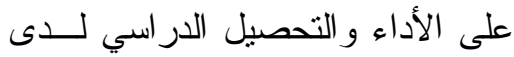

$$
\begin{aligned}
& \text { تلاميذ الصف السادس الابتدائي. } \\
& \text { ○. توجد علاقة ارتباطية بين التقويم القائم }
\end{aligned}
$$

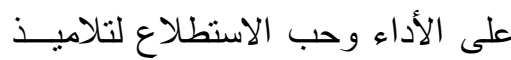

$$
\begin{aligned}
& \text { الصف السادس الابتدائي. } \\
& \text { يسعى للتعرف على مدى ممارســـة معلمــي لئي }
\end{aligned}
$$

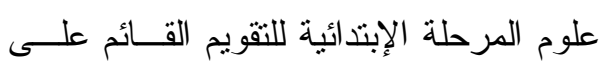

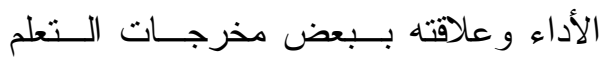

$$
\begin{aligned}
& \text { (التحصيل الدراسي-حب الاستطلاع) لـــــ } \\
& \text { تلاميذهم. } \\
& \text { مشكلة البحث: } \\
& \text { يمكن تحديد مشكلة البحث الحالي من خلال } \\
& \text { الإجابة علي السؤال الرئيس الآتي: }
\end{aligned}
$$

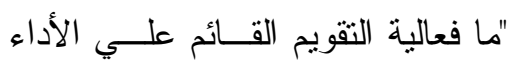

$$
\begin{aligned}
& \text { علي بعض مخرجات التعلم لطلاب المرحلـــة }
\end{aligned}
$$

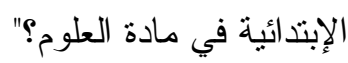

$$
\begin{aligned}
& \text { ويتفرع من هذا السؤال الــــئيس الأســـئلة } \\
& \text { الآّية: } \\
& \text { ( ) ما مدى ممارسة المعلمين للتقويم القائم } \\
& \text { على الأداء في العملية التدريسية؟ }
\end{aligned}
$$

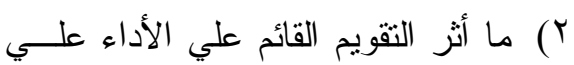

$$
\begin{aligned}
& \text { التحصيل الدراسي لاى تلاميذ الصف } \\
& \text { السادس الإبتدائي في مادة العلوج؟ }
\end{aligned}
$$

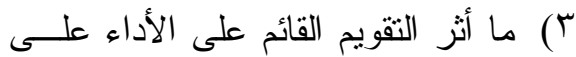

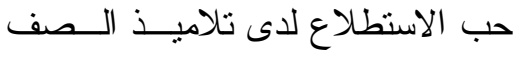

$$
\begin{aligned}
& \text { السادس الإبتدائى في مادة العلوم؟ } \\
& \text { ؛) إلي أي مدي توجد علاقة إرتباطية بين } \\
& \text { التقويم القائم علي الأداء و التحــــيل } \\
& \text { الدر اسي لدى تلاميذ الصف الـسادس }
\end{aligned}
$$

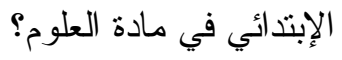


r) بطاقة ملاحظة لمعلمي العلوم. (من إعداد الباحثة) ع) مقياس حب الاستطلاع. (من إعـداد حدود البحث: الباحثة) تمنلت حدود البحث فيما يلي: 1. حدود مكانية: اقتصر البحث الحــالي لئي علـى (YV) مدرســـة تــابعين لإدارة

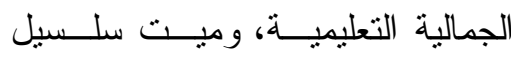

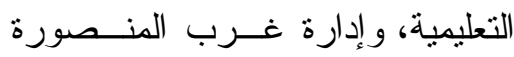
التعليمية، و بلقاس التعليمية بمحافظــــة وابدة الدقهلية. r. حدود زمنية: نت تطبيق البحث الحالي

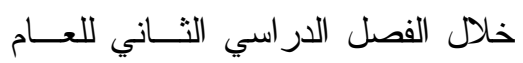

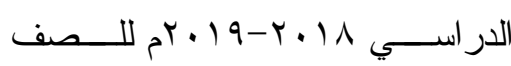
السادس الإبتدائي لمدة شهر ونصف. r. حدود موضوعية: تمثلت حدود البحث الموضوعية في وحدة الطاقة الكهربية"

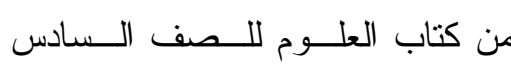
الإبتدائي للفصل الدر اسي الثاني لعـام

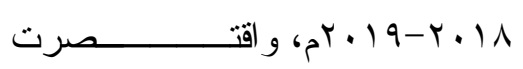

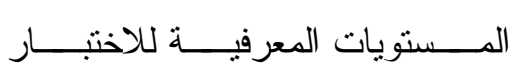

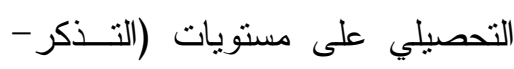

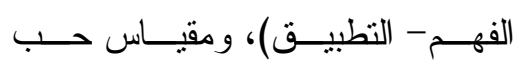
الاسنطلاع لتلاميذ الـصف الــسادس ومعاب الإبتدائي، و استبيان وبطاقة ملاحظــــة لمعلمي علوم المرحلة الإبتدائية.

\section{أهمية البحث:} يمكن أن يسهم البحث الحالي فيما يلي:

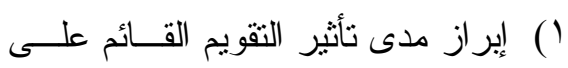

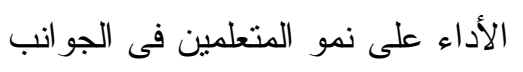

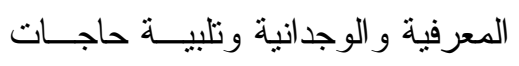

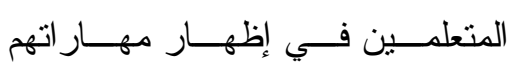
ومعارفهم بقيامهم بأداء معقد. Y (Y) توفير الوقت الذى يستغرقه المعلم في تقويم تلاميذه وتثرير النتائج ويُيــسر

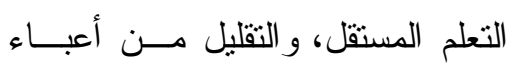

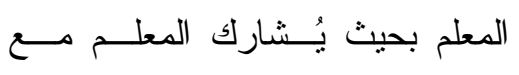
التلاميذ في عملية التعلم.

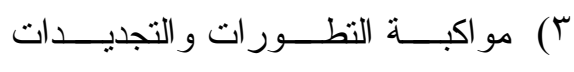
التربوية الحديثة.

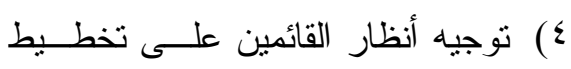
المناهج الدراسية نحو استخدام التقويم القائم على الأداء في التعليم الــصفي

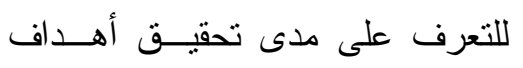
التعلم و اتخاذ نقطة بدء تعلم جديدة.

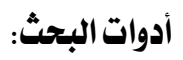
تمنلت أدوات البحث فيما يلي: ( ) اختبار تحــصيلي لمحتـوى الوحــدة

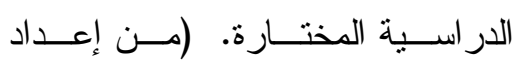
الباحثة) Y ) استبيان لمعلمي العلوم. (من إعــداد الباحثة) 
الحقـــائق و المفــــــــيم و التعميمـــــات

و القو انين و النظريات في وحدة "الطاقة

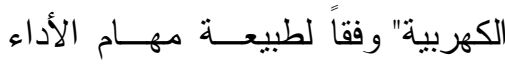

المستخدمة في مستويات التذكر و الفهم

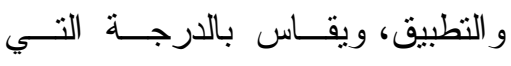

يحصل عليها التلميــذ فـــي الاختبـــار

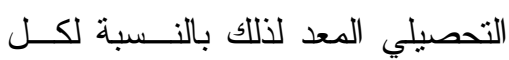

مستوى على حدة، وبالنسبة للاختبــار

ككل.

؛. . حـب الاســنطلاع: يُعــرف حـبـ

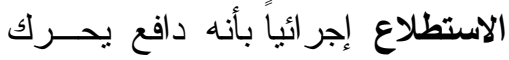

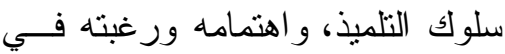

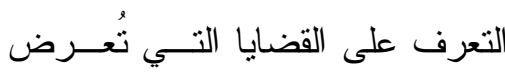

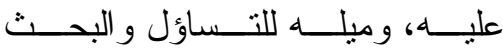

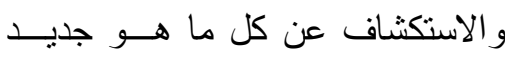

وتتمثل أبعاده فى الجدة و التساؤل عن

كل ما هو جديد و الفجائية من خــله وله

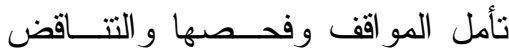

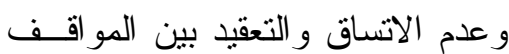

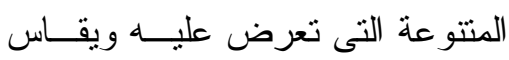

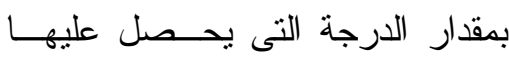

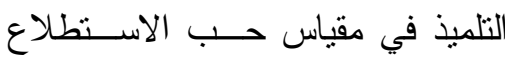

المُعد لذلك .

الإطار النظري للبحث:

المحور الأول: التقويم القــائم علـــى الأداء

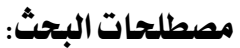

1. التقويم القـائم علــى الأداء: أحـــ

الاتجاهات الحديثة في مجــال تقــويم

المتعلم حيث يطلب من التلميذ تنفيــذ

الأنشطة و القبام بالمهار ات المتتوعـــة

وتوظيفها فى مو اقف و اقعية باستخدام

أساليب ومهام متتوعة مثل : الاجابات

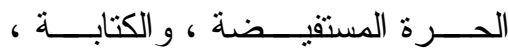

و التعبيــــر الـــشفوي، وعــــروض

الأعمـــــال،و التجــــــارب ، و الأداءات

العملية و اليدوية ،و إظهار مدى اتقانهم

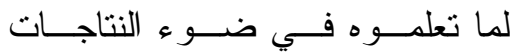

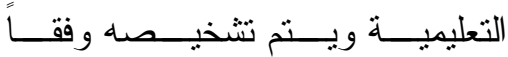

لاستجابات المعلمين على الأداة المعدة

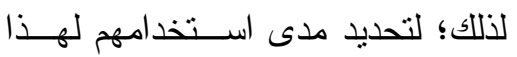

$$
\text { النوع من التقويم. }
$$

r. مخرجات التعلم: تُعـرف مخرجــات

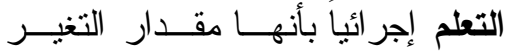

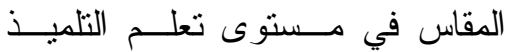

كمحصلة لما تم اكتسابه من معسارف

ومهار ات و اتجاهات وقيم فـي مــادة

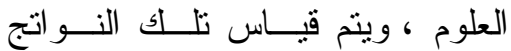

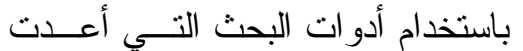

وفقاً للغرض من كل منها

r. التحصيل الاراسي: يُعرف التحصيل

الار اسي إجرائياً بأنه محصلة نتسائج

التلميذ من المعرفة العلمية المتمنلة في بله 
r. ثقويم يُحاكي و اقع الحياة حيث ثُقوم فيــــ

المهار ات المعرفية و الأدائية و الوجدانية.

ع. يُتيح للمتعلم فرصة الدفاع عـنـ أدائسـه

بتقديم الحجج و الأدلة و البراهين المنطقية

$$
\text { حول الأداء. }
$$

๑. يساعد في تعـديل الإجــر اءات ومهــام

التقويم لكل من المتعلم و المعلم ، بنـــاءً على التغذية الر اجعة من أي منهما. بعض صيغ مهام الأداء :

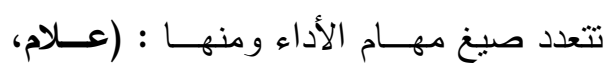

$$
\text { (Ir.-Irrugr...V }
$$

( ) الإجابات الحُرة أو المستفيضة: تتمثنـل

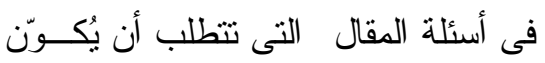
الطالب إجابته بنفسه بدلاً من أن يختــار الإجابة الصحيحة من بين بدائل معطـــاة

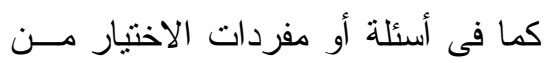

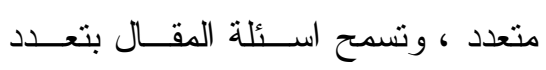
الاجابات.

Y) الكتابة: تُعد أسئلة المقال مثــالاً جيــــاً

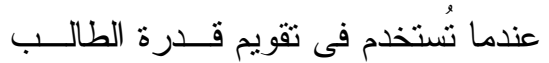

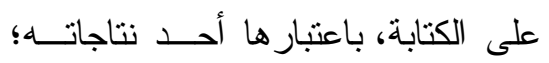
لذلك فإن تقويم كفاءة الطلبة في الكتابـــة

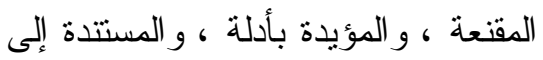

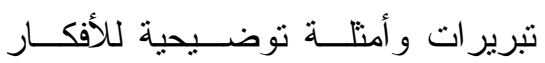
و التعميمات الني تتضمنها ، تتيح فرصاً كثيرة للطلبة لتحسين كتاباتهم.
هناك حاجة ملحة لتغيير نوعية التقويم

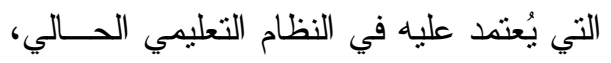

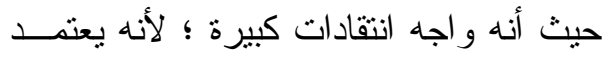
على أدنى مستويات المعرفة، وفي ظل التقدم

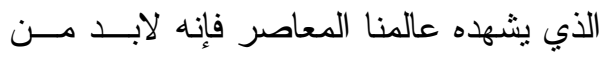

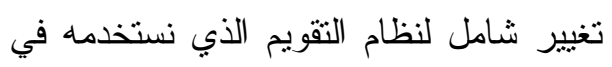
الفصول الدر اسية. تعريف التقويم القائم على الأداء: يُعرف (Stecher,2010, 3) التقويم القائم على الأداء بأنه عبارة عن مجموعــة

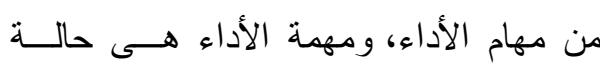

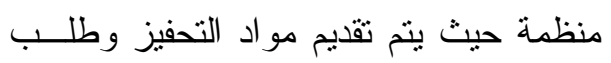
المعلومات أو الإجر اءات المقدمة إلى الفرد ،

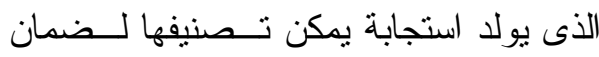

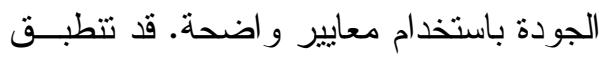
المعايير على المنتج النهائي أو على عمليــة فئة إنشائه. خصائص التقويم القائم على الأداء : يتميز التقويم القائم على الأداء بعـدد

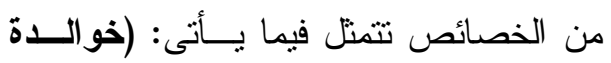

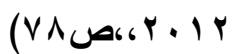
ا ـ يُتيح للمتعلم دوراً إيجابياً وفعـالاً فـي لو،ي التعلم و البحث عن المعلومة. r. يعد تقويماً متكاملاً لأنه يُركز على نقويم

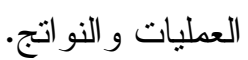




$$
\text { ا ـ تشديد الهدف أو الغاية مــن التقــويم }
$$

r. تحديد النتاجات الخاصة المراد تقويمها

بدقة.

r. تحديد ما يُر اد تقويمه بشكل دقيق من

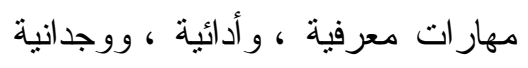

$$
\text { ، و و واجتماعية. }
$$

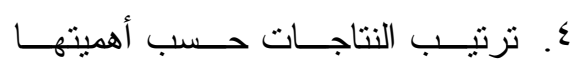

$$
\text { للمتعلمين. }
$$

○. انتقاء المهارات و العمليات المناســبة لطبيعة المتعلمين.

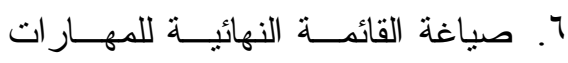

و العمليات المر اد تقويمها.

$$
\text { V. تحديد وقت لإنجاز المهام. }
$$

^. تحديد وصياغة معسايير ومسستويات

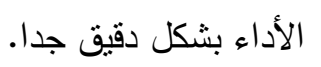

9. اختيار أداة التقويم المناســبة للمهــام

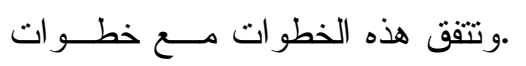

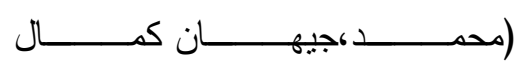

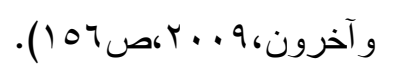

استخدام التقويم القائم على الأداء في مجال تدريس العلوم العلوم: - ت

هناك نسب متفاوتة في درجة استخدام

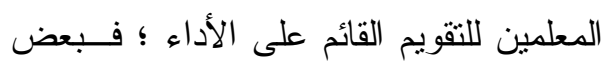
الدراسات تشير أنه الأسلوب الأفضل للتقويم r) التعبير الثفوى: تُشكل مهارات التعبير

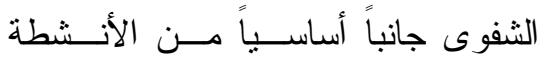

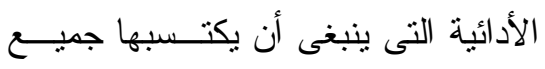

الطلبة، وبخاصة فى المرحلة الابتدائية،

حيث تُعد اختبار ات الأداء الثفوى أقــدم

$$
\text { صيغ تقويم الأداء. }
$$

ع) عروض الأعمال: تُعد عروض الأعمال

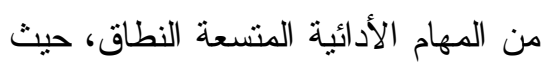

تتطلب أن يُيرز الطالب كفاياته المتعددة الادية

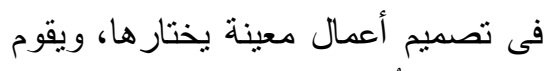

$$
\text { بتتفيذها، وتُعرض أمام الجمهور . }
$$

0) التجارب: تُعد التجــارب مــن المهــام

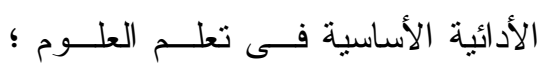

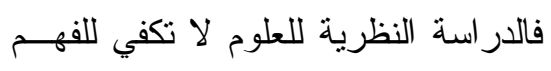

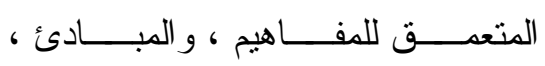
و النظريات ، و التصميمات العلمية ؛لذلك الكئ

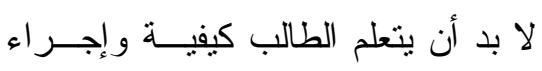
التجارب العملية في المختبرات.

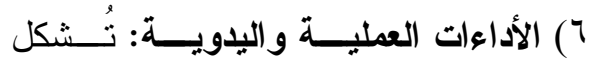

الأداءات العملية و اليدوية عنصراً الألية العهماً

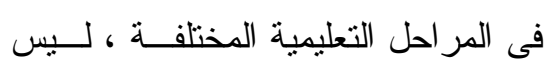
فقط في تدريس العلوم و الأنشطة العملية

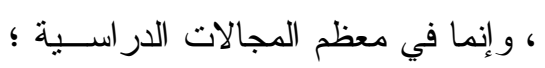

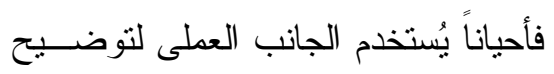
مفاهيم نظرية.

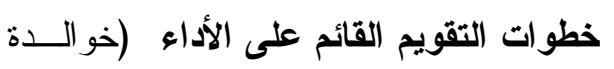

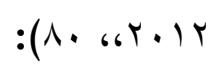


ممارسة معلمات العلوم فى مدينة المجمعسـة لأساليب التقويم البديل و أدو اته كان عالياً.

المحور الثانى : مخرجات التعلم في تعــيم

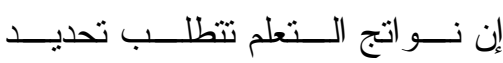

احتياجات التلاميذ وكل ما يكتسبه المتعلم من نئن

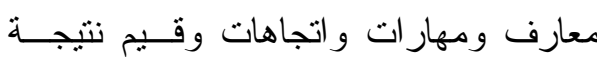

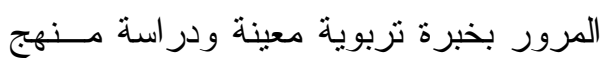

معين

تعريف مخرجات التعلم:

ويعــــ Iqual

(2018,p38)

إعطاء أو تحديد قيم للطلاب بناءً على معايير

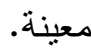

أهداف تقييم نواتج التعلم :

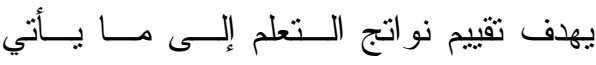

:(Brindley, 1998, 49-50)

1. . وضع المعايير المتوقعة من الإنجاز .

r. توفير إطار عمل مـشتشرك لتطــوير

المنهج.

r. توضيح أنو اع الأداء التي تؤدى إلـى

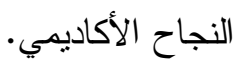

ع. دعم المعلمين في تتفيذ أهداف المنهج.

○. توفير قاعدة أساسية لتحديد مـصـادر

الاستهداف و التوزيع.
، و البعض يشثير أن هذا النوع مــن الثقــويم

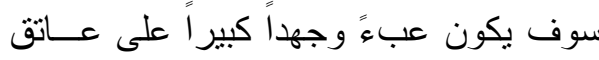

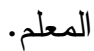

توصلت در اسة (الصلوى،V| • Y) إلى

أن درجة ممارسة معلمي العلــوم للتقـــويم القائم على الأداء بمحافظة العارضة بالمملكة العربيـــة الـسعودية متوســــة، ودر اســـة

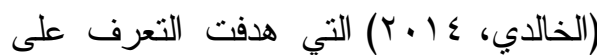
درجة ممارسة معلمـي العلــوم الطبيعيــة بالمرحلة المتوسطة لمهار ات التقويم البـديل

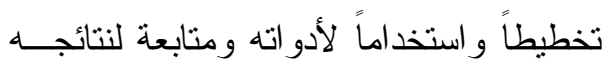
بمدينــة الطــائف بالــسعودية ، وتوصــلت

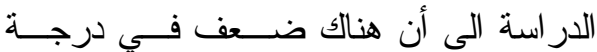
ممارسة معلمي العلوم الطبيعيــة لمهـار ات

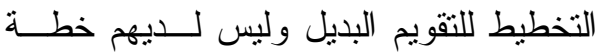
و اضحة ومحددة لجميع مر احل عملية النقويم ، كما أن هناكك ضعف في درجة ممارســة

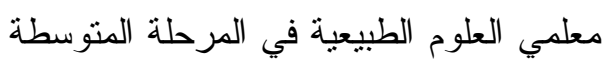
لمهار ات استخدام أدوات التقويم البديل ، كما أن هنالك ضعف في درجة ممارسة معلمـي لئي العلوم الطبيعية لمهار ات متابعة نتائج التقويم البديل، وفى در اسة (التزكي \& الــشمر اني

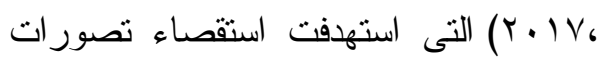
معلمات العلوم في مدينة المجمعة بالمملكـــة العربية السعودية حول التقويم البـديل مــن فئن حيث معرفتهن به وممارستهن له و اتجاهاتهن نحو ممارسته، وأظهرت النتائج أن مستوى ونهان 


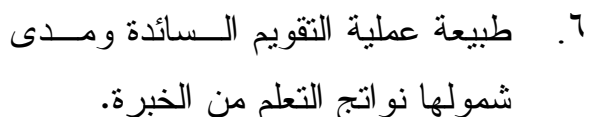

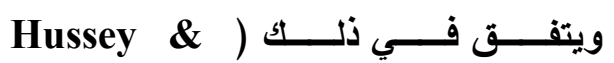

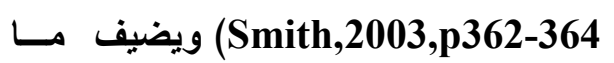

: يلي

ا. طبيعة العلاقة بين الطلاب و المعلمين

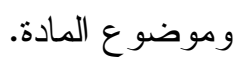

r. ـ طبيعة المناخ العـام داخــل الفـصل وهل

$$
\text { الدر اسي. }
$$

r. ـبيعة الاستر اتيجيات التي يسـستخدمها

$$
\text { المعلمين داخل الفصل الدراسي. }
$$

قياس مخرجات التعلم باستخدام اختبـــارات

$$
\text { الأداء : }
$$

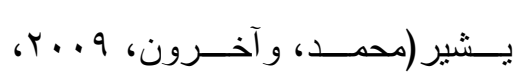

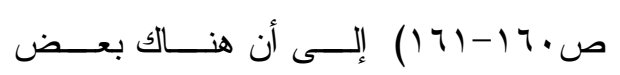

مخرجات التعلم التي يمكن قياسها باســتخدام

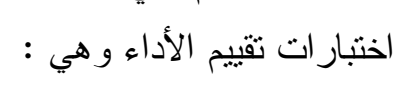

ا. التعامل مع البيانات و الحقائق الفنيـــة

$$
\text { المرتبطة بالعمل. }
$$

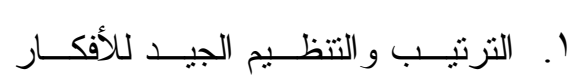

$$
\text { و الموضو عات. }
$$

r. التعبير اللفظي و الكتابي الــسليم عـن وضن

$$
\text { المعاني و الأفكار المر اد توصيلها. }
$$

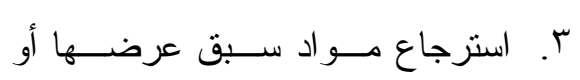

$$
\text { رؤيتها أو سماعها و تمييز ها. }
$$

7 ا. توفير نقاط مرجعية علـى مسستوى

النظام لمساعدة المعلمين فــي تقيــيم

$$
\text { التقدم الفردي. }
$$

V. توفير معلومات أكثر شمولاً لتقــديمها

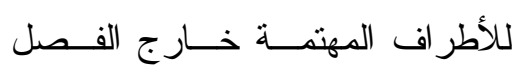

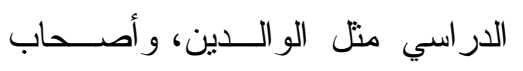

$$
\text { العمل و السلطات التعليمية. }
$$

العوامل التي تؤثر في نواتج التعلم :

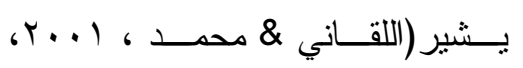

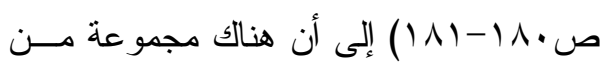

العو امل يمكن أن نؤثر في نواتج التعلم منها

ا. طبيعة الخبرة ذاتها من حيث عملهـا

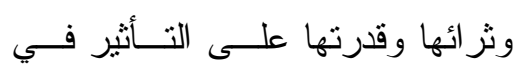

الفرد.

Y. جهذ المعلم في تتظيم الخبرة و إدار اتها

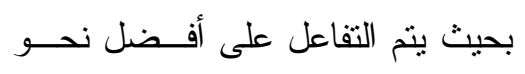

ممكن.

r. . وضوح الأهداف التي يرجى تحقيقهــا

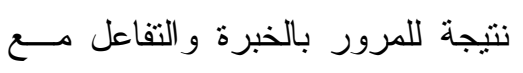

مكوناتها.

ع. العوامل المادية المؤثرة في مسستوى

حياة الفرد، والظــروف الإجتماعيــة

$$
\text { التي يعيشها. }
$$

๑. الخبرات الــسابقة لــدى الفــرد ذات

العلاقة بالخبرة الحالية. 


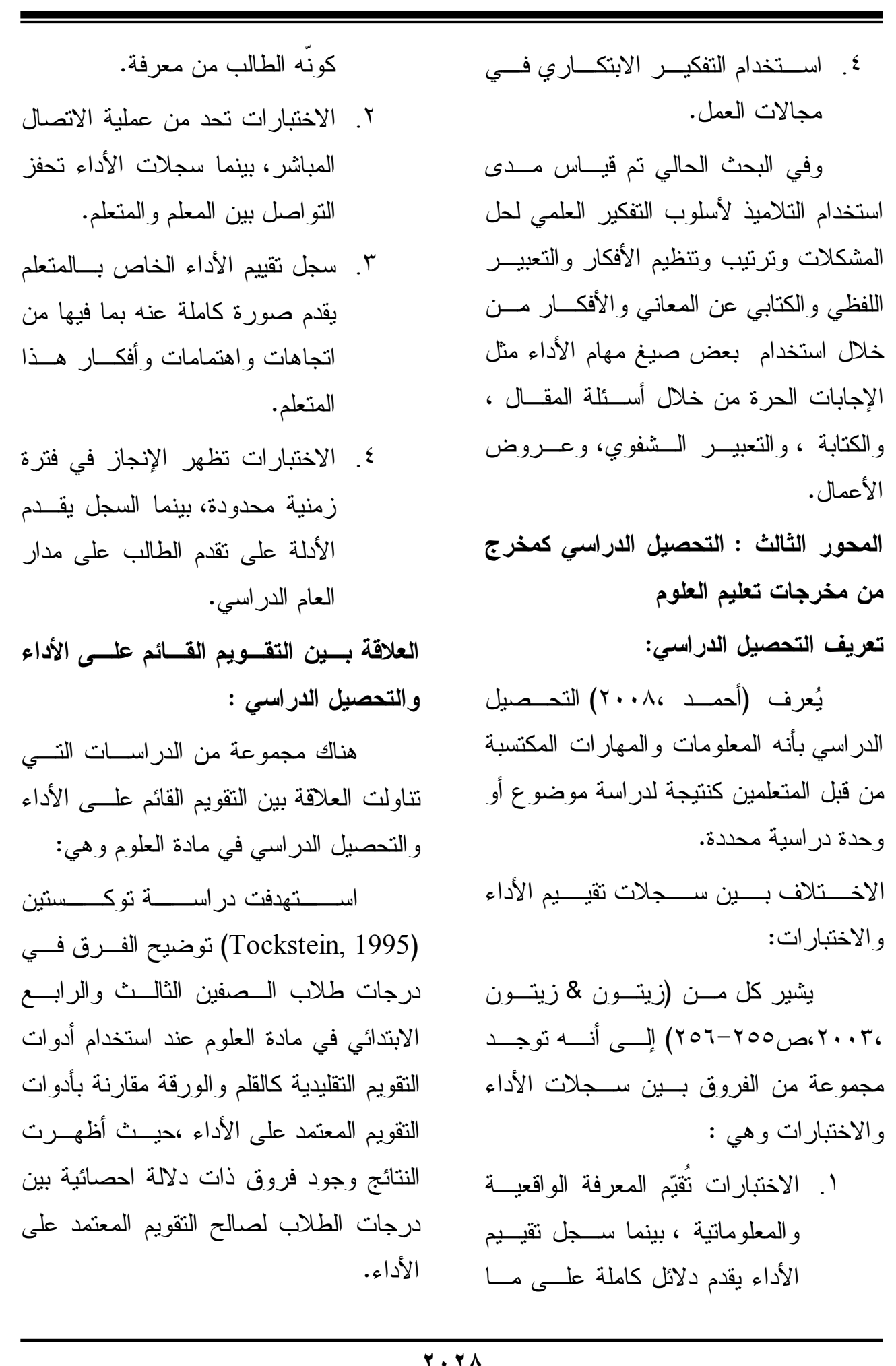




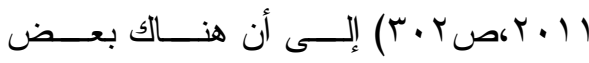

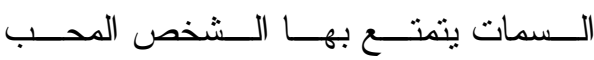

$$
\begin{aligned}
& \text { للاستطلاع وهي: } \\
& \text { 1. ـ دقيق الملاحظة. } \\
& \text { r. كثير التساؤل عن الأحداث و الظو اهر. } \\
& \text { r. كثير القر اعة للبحث عن المعلومات . } \\
& \text { ع. شديد الرغبــة فــي الاســتز ادة مــن }
\end{aligned}
$$

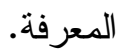

○. يرغب دائماً فـي معرفــة الأسـبـاب الحقيقة للظو اهر الطبيعية.

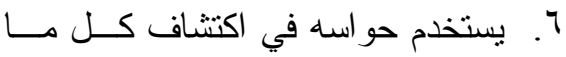
يتصل بالأحياء و الجمادات.

ومن خلال هذه الخصائص يتبــين أن من ضمن خصائص التقويم القائم على الأداء

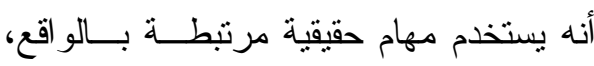
وإتاحة الفرصة لكل تلميذ للتطلع للبحث عن لن المزيد المعلومات، و استخدام أكثر من مهمة لتحقيق الهدف المطلوب؛ وبالتالي فإن التقويم القائم على الأداء يمكن أن بسهم فـــي إثــارة

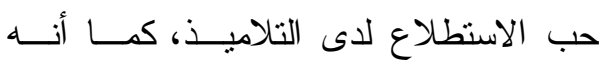

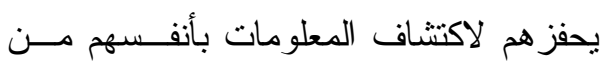
خلال مصادر متعددة . العلاقة بين التقويم القائم على الأداء وحب الاستطلاع :

Hill \& McGinnis ) (,2007,p54 إلى وجود علاقة بـين حـب الب الب
ودر اســة ( Parker \& Gerber, 2002 لنقويم طلاب الصف الخامس و السادس

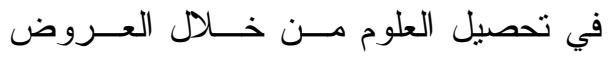
التقديمية ،وتوصلت الدراسة إلى أن التقــويم القائم على الأداء هو نهج مؤثر قابل للنطبيق لقياس المعارف و المهار ات لدى الطلاب.

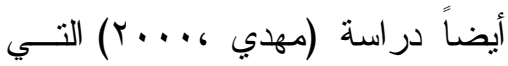

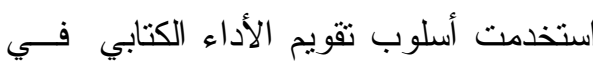

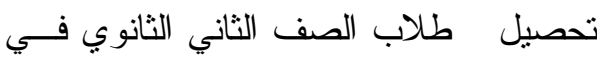
مادة الكيمياء في مدينة عدن ، وقد توصـلت الدر اسة إلى أن هناك فرق ذو دلالة إحصائية

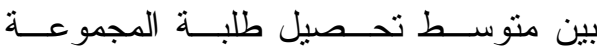

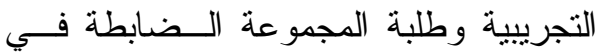
الاختبار التحــصيلي البعـدي يُعـزى إلـى استخدام أسلوب تقويم الأداء الكتابي. المحور الر ابع : حب الاستطلاع كمخرج من مخرجات تعليم العلوم تعريف حب الاستطلاع:

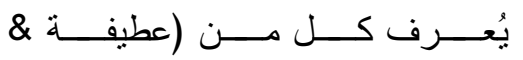
ســــورو، (1)

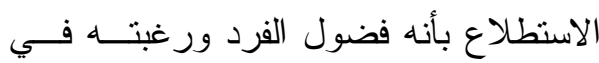
معرفة ما يجرى حوله من أحداث وميله إلى بلى

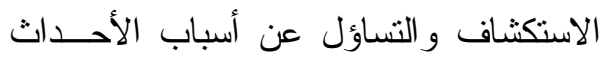
و الظو اهر · سمات الشخص المحب للاستطلاع : يشير كل من (عطيفـةهـ ســرور، 


$$
\begin{aligned}
& \text { ورغبتهم في اكتشاف كل ما هو جديد عـنـ } \\
& \text { الاستطلاع و الذاكرة و الأداء ، فعندما يكــون }
\end{aligned}
$$

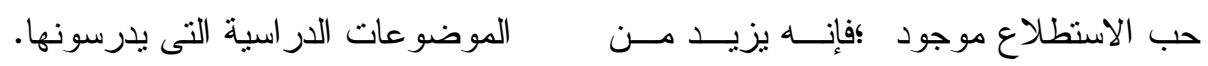

$$
\begin{aligned}
& \text { اهنمامات الأطفال ، ويتساعلون عن الأمسـور إجرائات البحث: }
\end{aligned}
$$

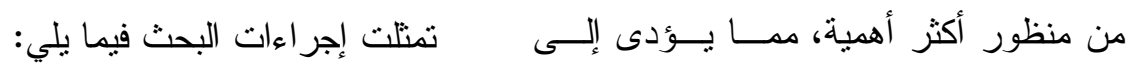

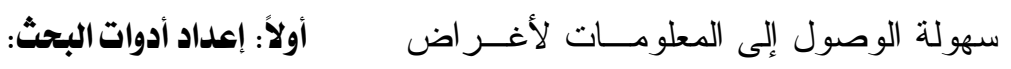

$$
\begin{aligned}
& \text { ( ) إعداد الإستبانة: تم إعــداد الإســتبانة } \\
& \text { وفقاً للخطوات التالية: } \\
& \text { أ. تحديد الهدف من الاستبانة: اســتهدفت } \\
& \text { الاستبانة المستخدمة في البحث الحالي } \\
& \text { معرفة مدي ممارسة معلمـي علــوم } \\
& \text { الصف السادس الإبتدائي للتقويم القــائم }
\end{aligned}
$$

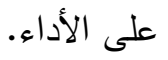

$$
\begin{aligned}
& \text { ب. تحديد أبعاد الاستبانة: قامــت الباحثتـة }
\end{aligned}
$$

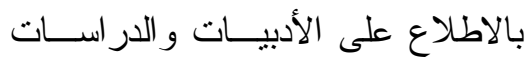

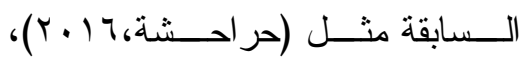

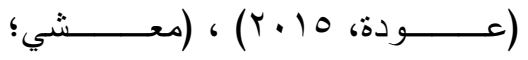

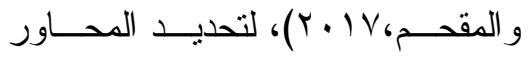

$$
\begin{aligned}
& \text { الرئيسية التـي تـضنمنتها الاسـنبانة } \\
& \text { وصياغة الفقر ات المتعلقة بكل محور. } \\
& \text { ج. صياغة عبار ات الاستبانة: تم تحديـــ } \\
& \text { نوع الاسنبانة من النوع المغلق، حيث }
\end{aligned}
$$

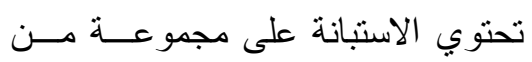

$$
\begin{aligned}
& \text { العبار ات تتطلب إجابات محددة (بدرجة }
\end{aligned}
$$

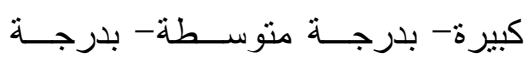

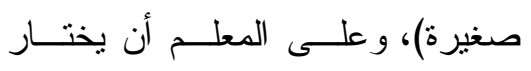

$$
\begin{aligned}
& \text { الإجابة التي ير اها مناسبة. وعثي } \\
& \text { لاحقة تنطوي على أسئلة متماتلة. }
\end{aligned}
$$

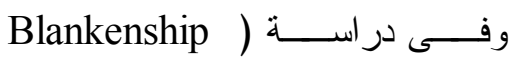

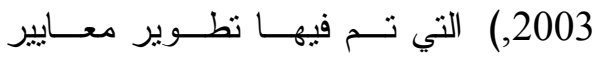

$$
\begin{aligned}
& \text { Wyoming للاستعد اد المبكر وذللك لتعظـــيم }
\end{aligned}
$$

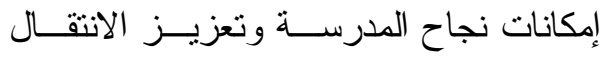

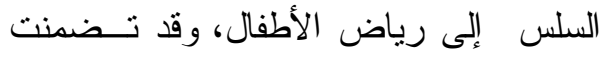

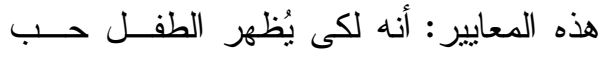

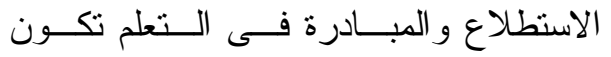

$$
\begin{aligned}
& \text { مؤشر ات الأداء كالتالي: يشارك فى مجموعة }
\end{aligned}
$$

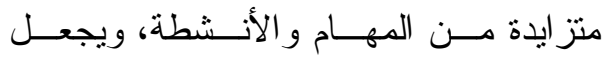

$$
\begin{aligned}
& \text { الاختيـــار ات مـسـتقلة ، ويُظهـــر المرونــــة }
\end{aligned}
$$

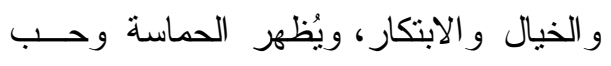

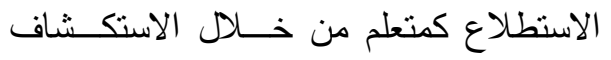

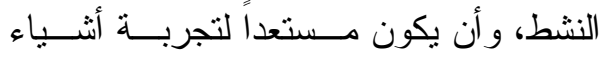

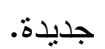

$$
\begin{aligned}
& \text { من خلال العرض السابق يتـضح أن }
\end{aligned}
$$

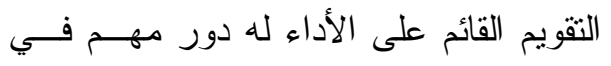

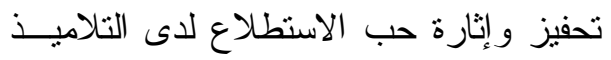

$$
\begin{aligned}
& \text { وأن هناك علاقة بين التقويم القائم على الأداء } \\
& \text { الذى يقوم على مهمات حقيقية أصيلة ، وبين }
\end{aligned}
$$

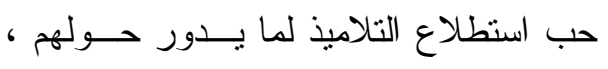


للاسنبانة، وذلك من خــلال حسـاب

معامل ارتباط درجــة كــل مفــردة

بالدرجة الكلية للمحور المنتمية إليــه،

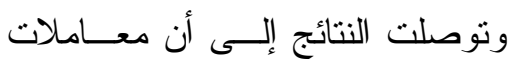

الارتباط جاءت دالة عند مستوي دلالة

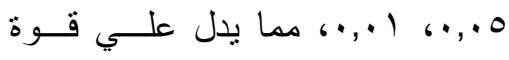

ارنباط العلاقة بين درجــة مفــردات

الاسنبانة بالدرجة الكلية للمحاور التي

$$
\text { تتمى إليها. }
$$

r. حساب معامل ارتبــاط درجــة كـلـل

محور بالدرجة الكلية للاسـتبانة: تـم

حساب معامل ارتبــاط درجــة كـلـل

محور بالارجــة الكليــة للاســنبانة،

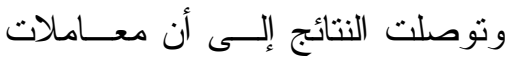

الارتباط موجبة وذات دلالة إحصائية

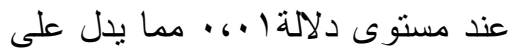

صدق الاتساق الداخلي للاسنبانة.

و. الدر اسة الاستطلاعية للاســنبانة: تـم

إجر اء الدر اسة الاستطلاعية للاســنبانة

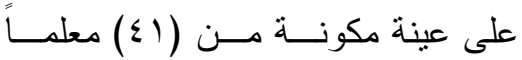

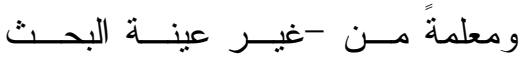

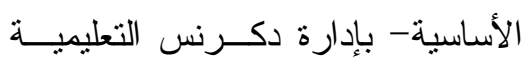

،وغرب المنصورة ،وشرق المنصورة

،وطلخا بمحافظة الدقهلية، وتم إجــر اء

التجربة الاسنطلاعية بهـدف تحقبـق

$$
\text { الأهداف الآتية: }
$$

د. وضع تعليمات الاستبانة: هناك بعـض

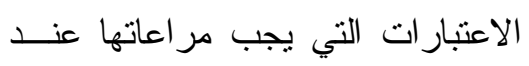

صياغة تعليمــات الاســنبانة، منهــا:

السهولة ، و الوضوح، و الاقتصاد فـي نياني

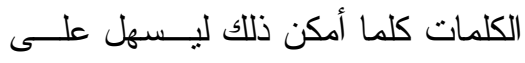

المعلم فهمها، كما نم الاستعانة بمثــال لمال

محلول لتوضيح كيفية الإجابة.

ه. صدق الاستبانة: بعد الانتهاء من إعداد

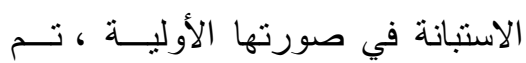

حساب الصدق مـن خــلال اســتخدام

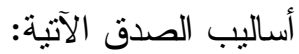

1. صدق المحكمين: تم عرض الاسنبانة

في صورتها الأولية على مجموعــة

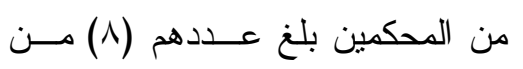

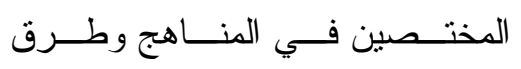

التدريس العلوم ، وقد أثنــار بعــ وض

المحكمين إلى حذف بعض العبــار ات

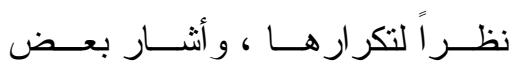

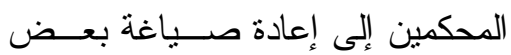

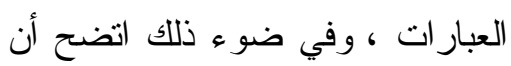

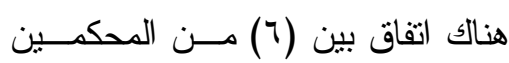

بنسبة . ^\% على تطبيق الاسـنبانة،

وقد تم إعادة صياغة بعض العبار ات،

وبذلك أصــبـت الاســنبانة جــاهزة

للنطبيق.

Y. حساب صدق الاتساق الـــاخلي: تــم

حـساب صـــدق الاتــساق الــــاخلي 
ب. تحديد أبعاد بطاقة الملاحظـــة: مــنـ

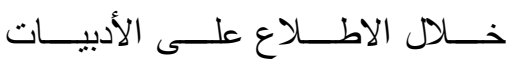

و الدر اسات السابقة ذات الصلة بالبحث الادي

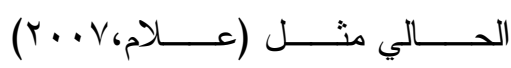

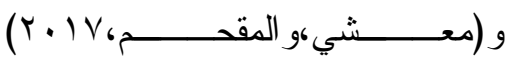

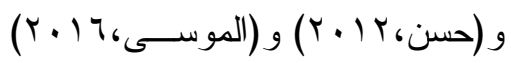

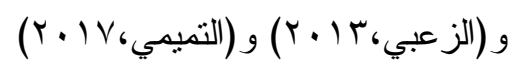

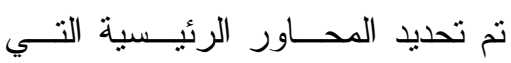

تضمنتها بطاقة الملاحظة وصــياغة

الفقر ات التي تقع تحت كل محور.

ج. صياغة عبار ات بطاقة الملاحظة: تـــ

صياغة عبار ات بطاقة الملاحظة مــع

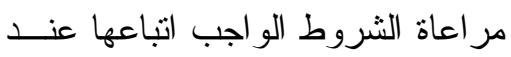

صياغة العبار ات من حيث وضــوح

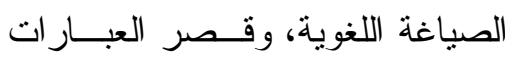

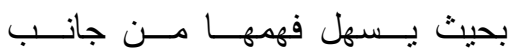

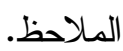

د. وضع تعليمات بطاقة الملاحظة: هناك

بعض الاعتبار ات التي يجب مر اعاتها

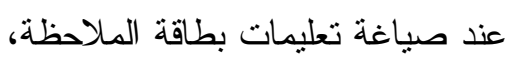

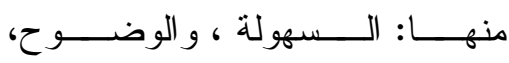

و الاقتصاد في الكلمات كلما أمكن ذلك وضك ولك

$$
\text { ليسهل على الملاحظ فهمها. }
$$

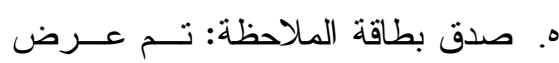

بطاقة الملاحظة في صورتها الأوليــة

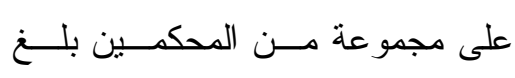

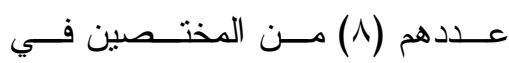

1. تحديد زمن الاستبانة: تـــ حسـاب

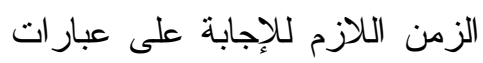

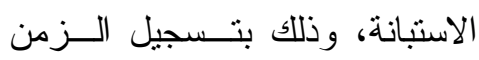

الذى استغرقه كل معلم من العينـــة

الاستطلاعية في الإجابة عن أسئلة

الاستبانة، ثم حساب متوسط الزمن فئه

$$
\text { اللازم للإجابة عن الاستبانة. }
$$

r. حساب ثبات الاستبانة بمعادلة ألفـــا

كرونباخ: نم حساب ثبات الاستبانة

بطريقة ألفا كرونباخ حيث تقوم هذه

الطريقة على حساب تباين مفردات

الاستبانة، وتوصلت النتائج إلى أن

معاملات الثبات لمحاور الاسـتبانة

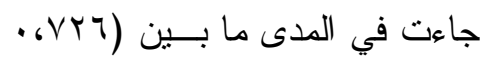

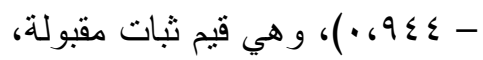

وبالنسبة للاستبانة ككل جاء معامل

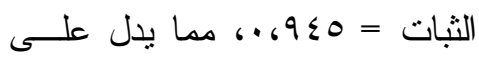

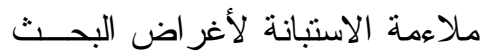

$$
\text { الحالي. }
$$

Y ) إعداد بطاقة الملاحظة: تم إعداد بطاقة الملاحظة وفقاً للخطوات التالية:

أ. تحديد الهدف من بطاقــة الملاحظــــة:

استهدفت بطاقة الملاحظة المستخدمة

في البحــث الحــالي معرفــة مــدي

ممارسة معلمي علوم الصف السادس

الإبتدائي للتقويم القائم على الأداء. 


$$
\begin{aligned}
& \text { البحث الحالي قياس مستوى تحــصيل }
\end{aligned}
$$

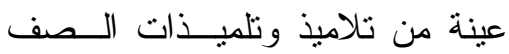

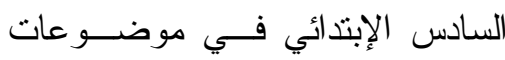

$$
\begin{aligned}
& \text { وحدة " الطاقة الكهربية". }
\end{aligned}
$$

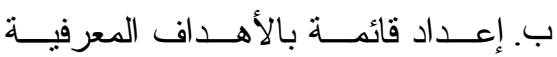

$$
\begin{aligned}
& \text { المتضمنة في الوحدة: قد بلغ عدد هذه } \\
& \text { الأهداف عشرون هدفاً سلوكياً . } \\
& \text { ج. تحديد المستويات المعرفية للاختبـار }
\end{aligned}
$$

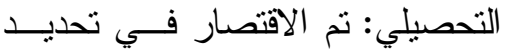

$$
\begin{aligned}
& \text { المستويات المعرفية المتـــنة فــي } \\
& \text { الاختبار على المـستويات المعرفيــة } \\
& \text { الثلاثة الأولي من المستويات الـستة }
\end{aligned}
$$

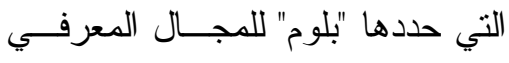

$$
\begin{aligned}
& \text { وذلك باعتباره أكثر التصنيفات شيوعاً } \\
& \text { و هي (التذكر -الفهم-النطبيق). } \\
& \text { د. إعداد جدول المو اصفات: تـــم تقـسيم } \\
& \text { وحدة "الطاقة الكهربية" إلي مجموعـــة } \\
& \text { من الموضوعات، وتحليل الوحدة إلى وهلى } \\
& \text { مجمو عة من الأهداف ، بعد ذللك تــم وند }
\end{aligned}
$$

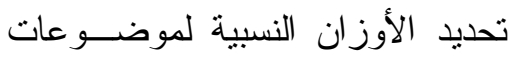

$$
\begin{aligned}
& \text { وحدة " الطاقة الكهربية" وكذلك تحديد } \\
& \text { الأوزان النسبية للمستويات المعرفيــة } \\
& \text { الثناثة (التذكر - الفهم-التطبيق) ، وقد }
\end{aligned}
$$

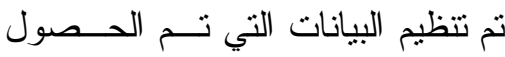

$$
\begin{aligned}
& \text { عليها في جدول ثنائي التصنيف، كما } \\
& \text { يحدده الجدول التالي: } \\
& \text { المناهج وطرق تــدريس العلــوم، و }
\end{aligned}
$$

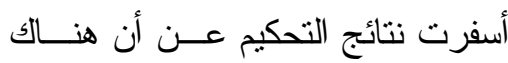

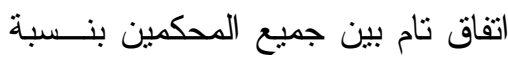

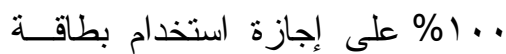

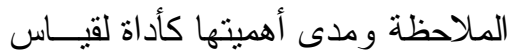

$$
\begin{aligned}
& \text { مدى ممارسة معلمي علوم المرحلـــة } \\
& \text { الإبتدائية للتقويم القائم على الأداء. } \\
& \text { و. ثبات بطاقة الملاحظة: للتحقـق مــن } \\
& \text { ثبات بطاقة ملاحظة مهار ات التقـــويم }
\end{aligned}
$$

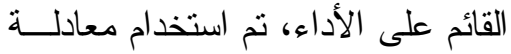

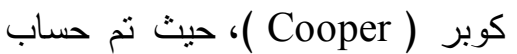

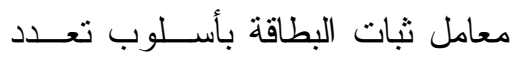

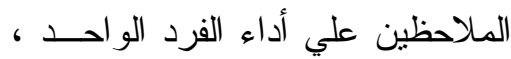

$$
\begin{aligned}
& \text { وتم حسـساب معامـلـ الاتفــاق بــين }
\end{aligned}
$$

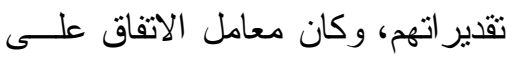

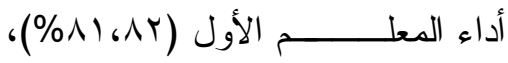

$$
\begin{aligned}
& \text { ومعامل الاتفاق على أداء المعلم الثاني } \\
& \text { (9، •9\%)، ومعامل الاتفاق على أداء }
\end{aligned}
$$

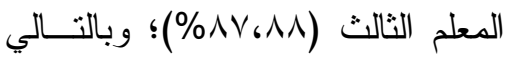

$$
\begin{aligned}
& \text { فإن متوسط معامل اتفاق الملاحظــين } \\
& \text { في حالة المعلمــين الثنلاتــة يسـساوي }
\end{aligned}
$$

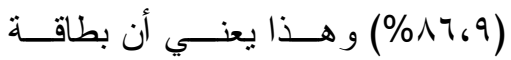

$$
\begin{aligned}
& \text { الملاحظة علي درجة من الثبات و إنها } \\
& \text { صالحة كأداة قباس. } \\
& \text { ץ) إعداد الاختبار التحـصيلي: تـــم إعــداد } \\
& \text { الاختبار التحصيلي وفقاً للخطوات التالية: } \\
& \text { أ. تحديد الهدف من الاختبار : اســتهدف }
\end{aligned}
$$

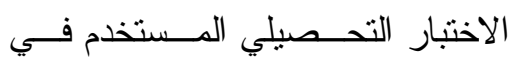




\begin{tabular}{|c|c|c|c|c|c|}
\hline \multicolumn{6}{|c|}{ جدول( ) مواصفات الاختبار التحصيلي لوحدة "الطاقة الكهربية" } \\
\hline اللموضوعات النسبية & | المجموع | & 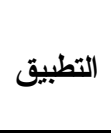 & 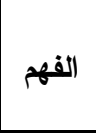 & التذكر & مستويات الأهداف \\
\hline$\%$ \% & r. & - & $\wedge$ & $v$ & المصابيح الكهربية \\
\hline \multirow[t]{2}{*}{$\% r r$} & 1. & $r$ & $\varepsilon$ & $r$ & أخطار الكهرباء وكيفية التعامل معها \\
\hline & r. & & & & مجموع الأسئلة \\
\hline$\% 1 \ldots$ & & \%ro & $\% \varepsilon$ & \%ro & الأهمية النسبية للمستويات \\
\hline \multicolumn{4}{|c|}{ بمهام الأداء الخاصة بها ، وملاءمة } & \multicolumn{2}{|c|}{ ه. تحديــــد نـــوع عفــردات الاختبــــار } \\
\hline \multicolumn{4}{|c|}{ الاختبار لقياس المستويات المعرفية } & \multicolumn{2}{|c|}{ وصياغتها: تم تحديد نوعيــة أســئلة } \\
\hline \multicolumn{4}{|c|}{ المر اد تتميتها ، و اتضـح أن هنــاك } & \multicolumn{2}{|c|}{ الاختبار من نوع الأسئلة المقالية حيث } \\
\hline \multicolumn{4}{|c|}{ اتفاق تام بين جميع المحكمين بنسبة } & \multicolumn{2}{|c|}{ يُطلب من التلميــذ أن يكتــب مقــالاً } \\
\hline \multicolumn{4}{|c|}{ 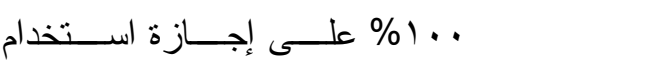 } & \multicolumn{2}{|c|}{ يتكون من عدة فقرات أو جمل علــى } \\
\hline \multicolumn{4}{|c|}{ الاختبار ، وبذلك أصبح الاختبار في } & \multicolumn{2}{|c|}{ السؤال المطلوب، وفي ضوء ذلك تم } \\
\hline \multicolumn{4}{|c|}{ صورته الأولية صــالحاً للنطبيـق } & \\
\hline \multicolumn{4}{|c|}{ على عينة البحث الاسنطلاعية. } & \multicolumn{2}{|c|}{ صلغت (·باغة اسئلة الاختبار التحصيلي وقد } \\
\hline \multicolumn{4}{|c|}{ r. التجربــة الاســتطلاعية للاختبـــار } & \multicolumn{2}{|c|}{ و. الضبط العلمي للاختبار ( المحـددات } \\
\hline \multicolumn{4}{|c|}{ التحصيلي: بعد التأكد من صلاحية } & \multicolumn{2}{|c|}{ السيكومنرية) ، وتضمن : } \\
\hline \multicolumn{4}{|c|}{ الصورة الأولية للاختبار التحصيلي } & \multicolumn{2}{|c|}{ ا. ــــدق المحكـــين: تــم عـرض } \\
\hline \multicolumn{4}{|c|}{ وصدق مفرداته فــي ضـــوء مــــا } & \multicolumn{2}{|c|}{ الـــــصورة المبدئيـــــة للاختبـــــار } \\
\hline \multicolumn{4}{|c|}{ أسفرت عنه نتائج العــرض علــى } & \multicolumn{2}{|c|}{ التحصيلي علــى مجموعـــة مــن } \\
\hline \multicolumn{4}{|c|}{ المحكمـــين وإجـــر اء التعـــديلات } & \multicolumn{2}{|c|}{ المحكمين بلــنغ عـددهم (^) مــن } \\
\hline \multicolumn{4}{|c|}{ المطلوبة ، تـــــــــــر إه التجربــة } & \multicolumn{2}{|c|}{ أعضاء هيئة التدريس المتخصصين } \\
\hline \multicolumn{4}{|c|}{ الاسنطلاعية للاختبار على عينــة } & 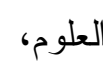 & في المناهج وطرق تدريس \\
\hline وتلميــذات الـــصف & لــن تلاميــا & & & عـن & وقد أسفرت نتــائج التحكــيم \\
\hline ي - غيــر عينـــة & لسادس الإب & & & كدافـه & سلامة تعليمات الاختبار وأه \\
\hline " - بمدرسة حوض & لبحث الأسا & & & ـــ & ووضوحها ، وسلامة مفرداتة \\
\hline بتثائية التابعة لإدارة & عبد اللطيف & & & 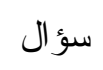 & الناحية العلمية ، وارتباط كل \\
\hline
\end{tabular}


ت- حساب معامل السهولة و الــصعوبة

ومعامل التمييز لمفردات الاختبار :

تم حساب معامل سهولة وصعوبة

كل مفردة من مفردات الاختبـــار؛

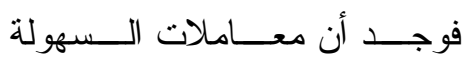

انحصرت ما بين (ץ، .-1ه، •).

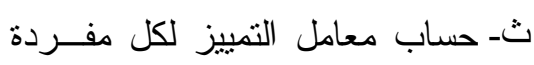

من مفردات الاختبار ، وكان فـي لئي

المدى المقبول حيث تر اوح ما بين

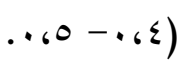

ج- حساب الاتساق الداخلي: تم حساب

صدق الاتساق الداخلي للاختبــار

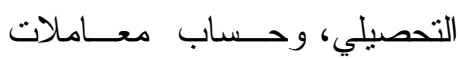

ارتباط درجة كل مفردة بالدرجـة ولئة

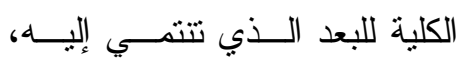

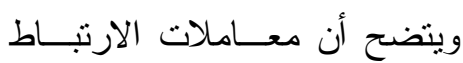

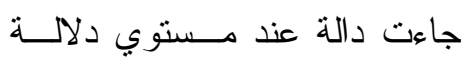

1.،.، مما بدل علي قوة العلاقة

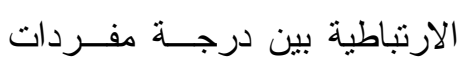

الاختبار التحصيلي بالدرجة الكلية

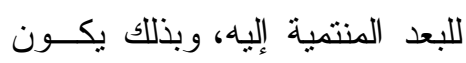

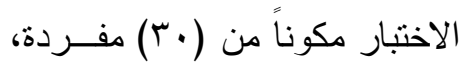

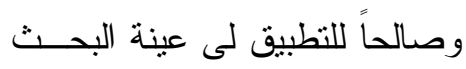

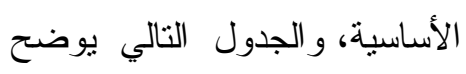

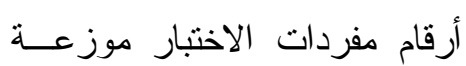

على المستويات المعرفية كما يلي:
الجمالية التعليمية، بلغ عدد التلاميذ

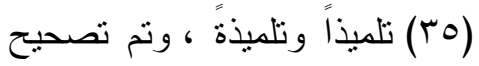

الاختبار ورصد الدرجات لكل تلميذ

وتلميذة؛ لتحقيق أهـــاف التجربــة ورجة

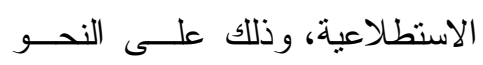

التالي:

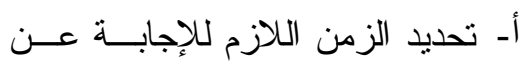

الاختبار: تم حساب الزمن اللازم

لتطبيق الاختبار التحصيلي؛ وذلك

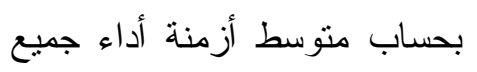

التلاميذ على أسئلة الاختبار ، وقد

بلغ الزمن اللازم لتطبيق الاختبار

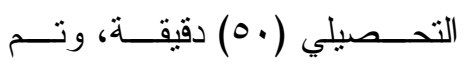

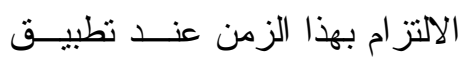

الاختبار على عينة البحث.

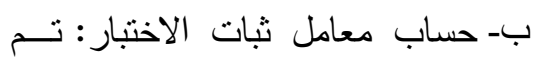

حساب ثنات الاختبار بطريقة ألفا

كرونباخ حيث تقوم هذه الطريقـــة

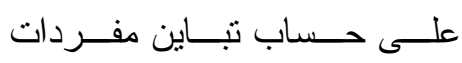

الاختبار ، و التي يتم مـن خلالهــــا

بيان مدى ارتباط مفردات الاختبار

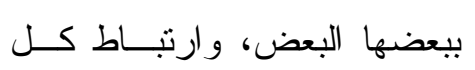

مفردة مع الدرجة الكلية ، و اتضح

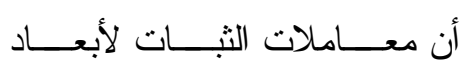

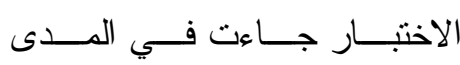

(1)

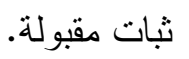




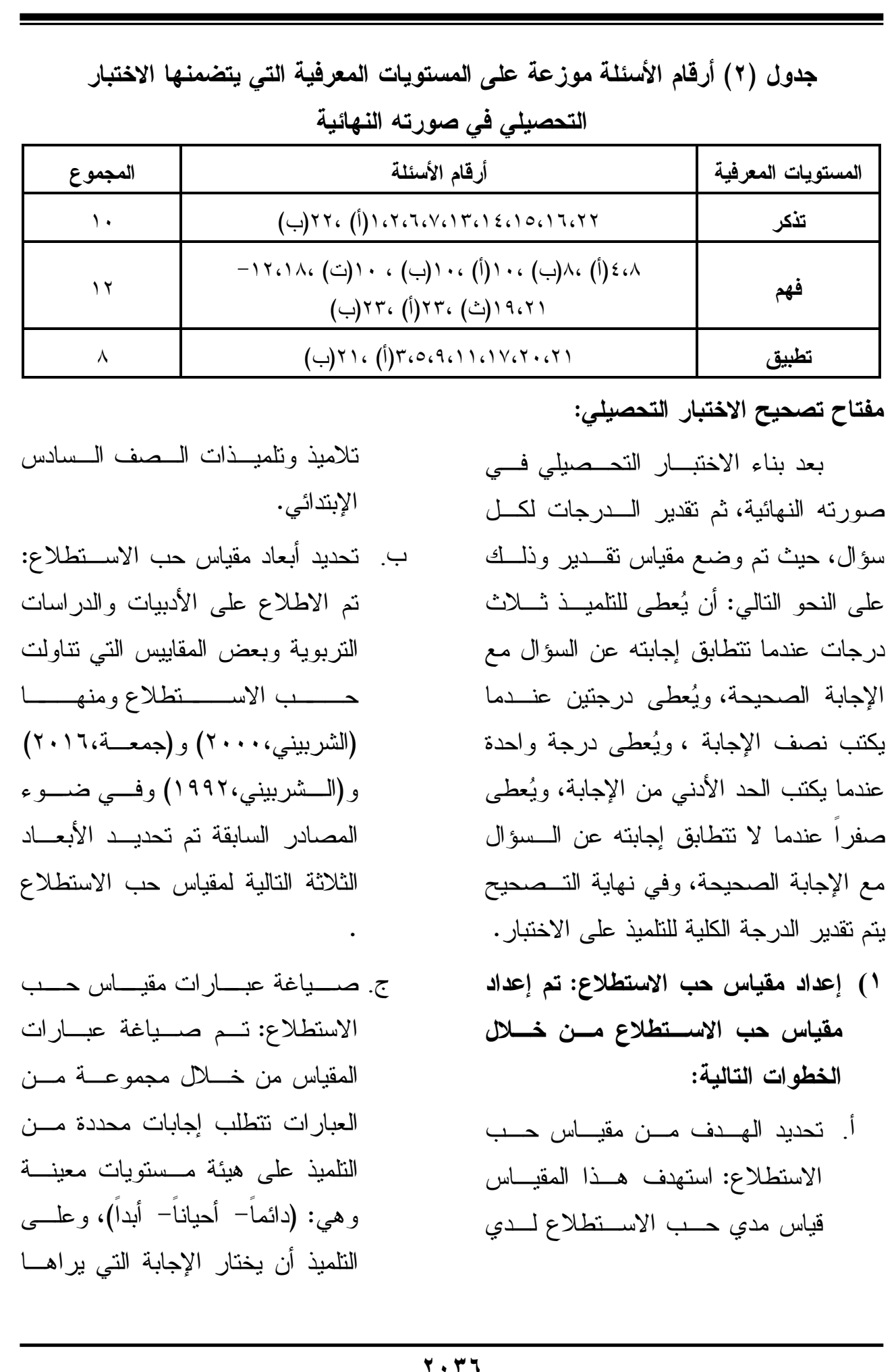




$$
\begin{aligned}
& \text {. . . 1 على إجازة استخدام مقياس } \\
& \text { حب الاستطلاع. } \\
& \text { r. صدق الاتساق الداخلي: نم حسساب }
\end{aligned}
$$

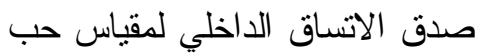

$$
\begin{aligned}
& \text { الاستطلاع، وذلك من خلال حساب الاب } \\
& \text { معامل ارتباط درجة كـلـل مفــردة } \\
& \text { بالدرجة الكلية للبعد المنتمية إليــه، } \\
& \text { وقد جاءت معاملات الارنباط دالة }
\end{aligned}
$$

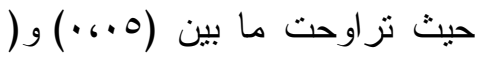

$$
\begin{aligned}
& \text { (.••)، مما يدل علي قوة العلاقة } \\
& \text { الارنباطية بـين درجــة مفــردات } \\
& \text { مقياس حب الاســنطلاع بالدرجــة } \\
& \text { الكلية للأبعاد المنتمية إليها. } \\
& \text { r. حساب معامل ارتباط درجة كل بعد }
\end{aligned}
$$

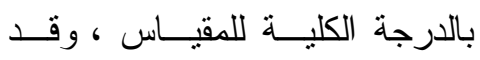

$$
\begin{aligned}
& \text { توصلت النتائج إلى أن معساملات }
\end{aligned}
$$

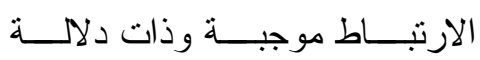

$$
\begin{aligned}
& \text { إحصائية عند مستوى دلالـــة ا.،. } \\
& \text { مما يدل علـى صــدق الاتـساق } \\
& \text { الداخلي لمقياس حب الاستطلاع. } \\
& \text { و. الدراسة الاستطلاعية للمقيــاس: تـــ }
\end{aligned}
$$

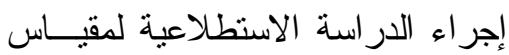

$$
\begin{aligned}
& \text { حب الاستطلاع على عينة مكونة من الن الناء }
\end{aligned}
$$

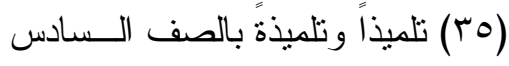

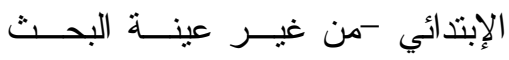

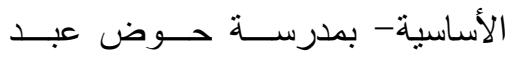

$$
\begin{aligned}
& \text { اللطيف الإبتدائيــة بــإدارة الجماليـــة }
\end{aligned}
$$

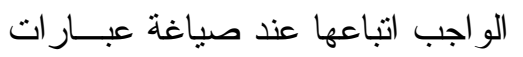

$$
\begin{aligned}
& \text { المقياس من حيث وضوح الــصياغة }
\end{aligned}
$$

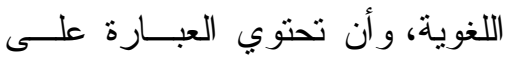

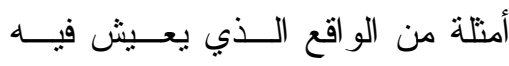

$$
\begin{aligned}
& \text { التلميذ. } \\
& \text { د. وضــــع تعليمـــات مقيـــاس حـــب } \\
& \text { الاسنطلاع: تم إعداد نعليمات المقياس } \\
& \text { في صورة ملائمة بسهل فهمها مسن }
\end{aligned}
$$

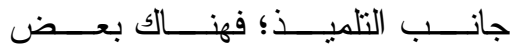

$$
\begin{aligned}
& \text { الاعتبار ات نم مر اعتها عند صــياغة }
\end{aligned}
$$

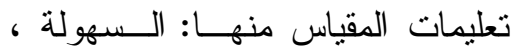

$$
\begin{aligned}
& \text { و الوضوح، و الاقتصاد فــي الكلمــات } \\
& \text { كلما أمكن ذللك ليسهل علــى التلميــذ } \\
& \text { فهمها. } \\
& \text { ه. صدق المقياس: نم التحقق من صــدق } \\
& \text { المقياس كالتالي: }
\end{aligned}
$$

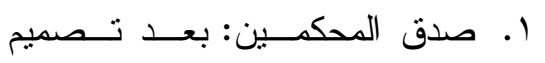

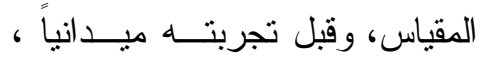

$$
\begin{aligned}
& \text { كان لابد من التأكد مـن صـــلاحية } \\
& \text { الصورة المبئية له، وذللك بعرضه }
\end{aligned}
$$

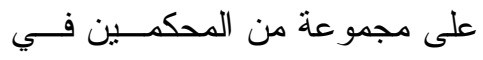

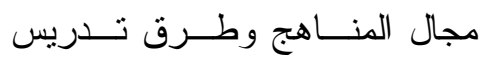

$$
\begin{aligned}
& \text { العلوم، وبلغ عددهم (^)، و اتـضخح وهن }
\end{aligned}
$$

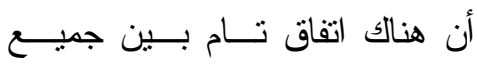

$$
\begin{aligned}
& \text { المحكمـين وعـددهم (^) بنـسبة هين }
\end{aligned}
$$




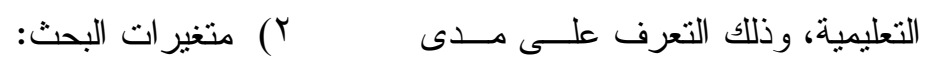

المتغير المستقل: التقويم القائم علـىى

وضوح عبار ات المقياس، وتم الطلب

الأداء.

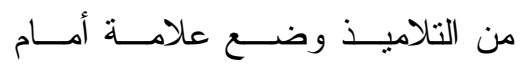

المتغير ات التابعة: مخرجــات الــتعلم

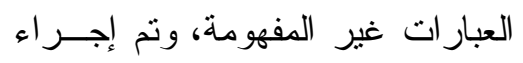

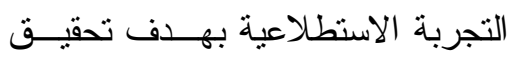

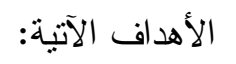

\section{ثالثاً: عينة البحث:}

تكونت عينة البحث من عـدد (§ᄉ)

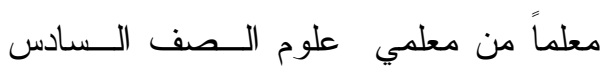

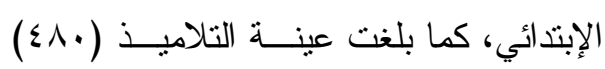
تلميذاً من نلاميذ الصف الــسادس الإبتــدائي للفصل الدراسي الثاني من العـام الدراسـي الدي

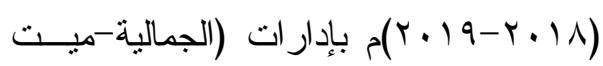
سلسيل بلقاس-غرب المنصورة) التعليميــة بمحافظة الدقهلية. أولاً: النتائج المتعلقة بالسؤال الأول: للإجابة عن الــسؤال الأول للبحـــث الذي نص على:" ما مدى ممارسة المعلمــين

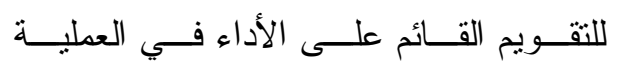

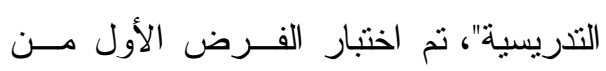

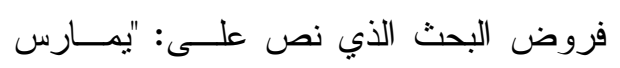

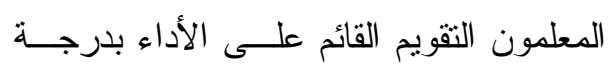

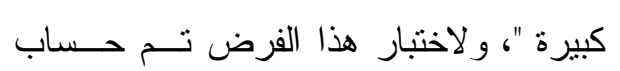

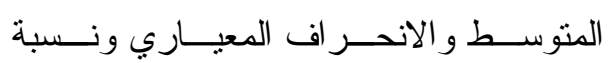

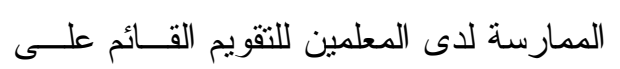

1. تحديد زمن المقياس: تــم حسساب

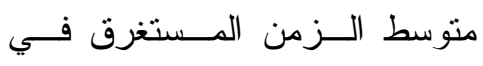
الإجابة عن المقياس، ليكون متوسط الزمن لمقياس حسب الاسـنطلاع

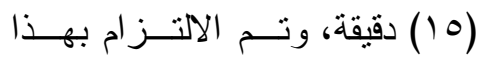
الزمن عند تطبيق المقيــاس علــى ونى عينة البحث.

Y. حساب ثبات المقياس بمعادلة ألفـــا

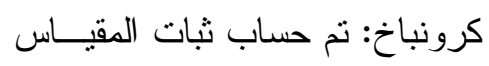

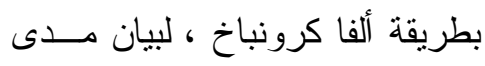

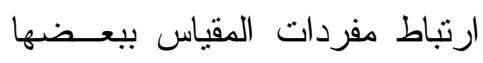
البعض، وارتباط كل مفـردة مــع

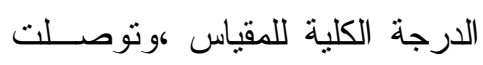

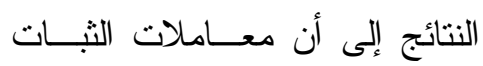

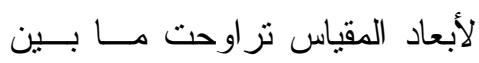

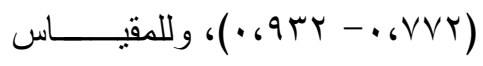

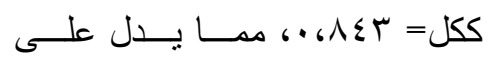
ملاعمة المقياس لأغر اض البحث. ثانياً: منهج البحث ومتغيراته:

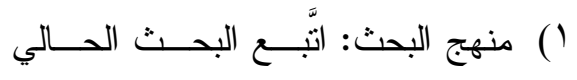
المنهج الوصفي البن 
والانحـــر اف المعيـــاري ونــــــة

الممارسة ودرجة الممارسة للتقويم

القائم على الأداء لدى المعلمين .
الأداء، وذللك من خلال الاســـنبانة وبطاقــة الملاحظة كما بلي:

أ- بالنسبة للنتائج الخاصة بالاستبانة: يوضـــح جــدول (ب) المتوســــ

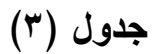

المتوسط والاتحر اف المعياري ونسبة الممارسة للتقويم القائم على الأداء لاى المعلمين

\begin{tabular}{|c|c|c|c|c|c|}
\hline الترتيب & الممارسة & نسبة الممارسة & الآحر اف & المتوسط & محاور الاستبانة \\
\hline$\varepsilon$ & منوسطة & $\% 79.7 V$ & דצדאי. & $r_{6} \cdot 9$ & 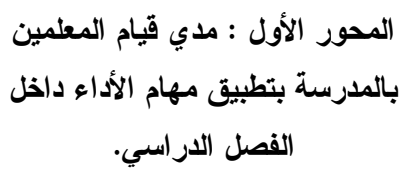 \\
\hline 1 & كبيرة & \% & $.6 r \cdot 7$ & r.07 & المحور الثاني: أنواع مهام الأداء \\
\hline r & كبيرة & $\% \vee \wedge, 7 \vee$ & . . & T.rT & التحور الثالث: مزايا استخدام \\
\hline r & كبيرة & \%V9, & $\cdot ، \Sigma \wedge V$ & r.rA & 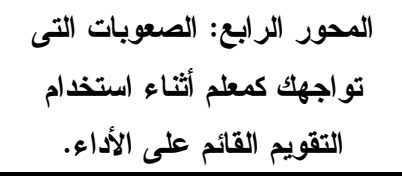 \\
\hline \multicolumn{2}{|c|}{ كبيرة } & \%VA,rr & $.6 r \wedge \varepsilon$ & trito & الدرجة الكلية للاستباتة \\
\hline
\end{tabular}

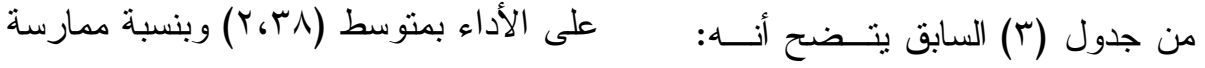

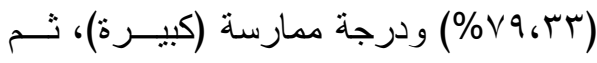

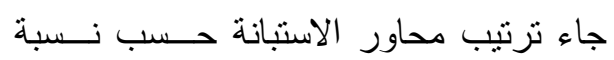
مز ايا استخدام التقــويم القــائم علـــى الأداء

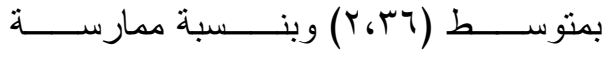

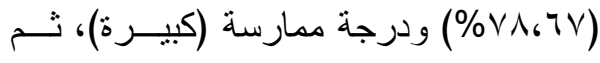

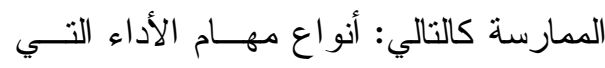

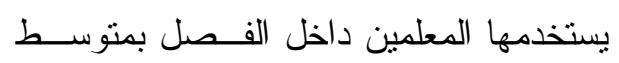

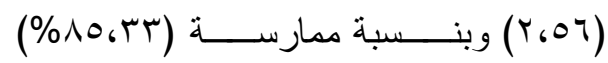
مدي قيام المعلمين بالمدرسة بتطبيــق مهــام ودرجة ممارسة (كبيرة)، ثم الصعوبات التي ولي

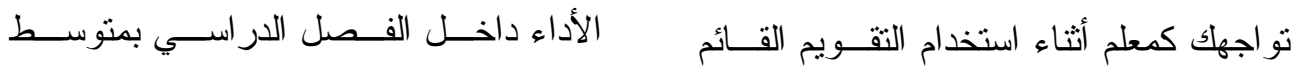

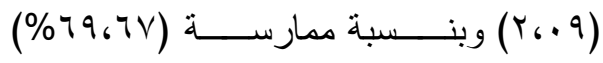




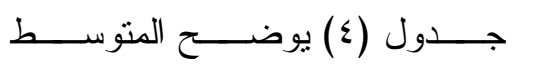

و الانحر اف المعيــاري ونــسبة الممارســـة ودرجة الممارسة للتقويم القائم علـى الأداء لدى المعلمين.

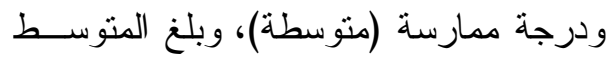

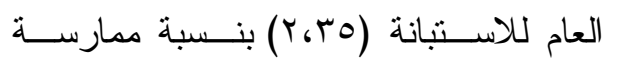
(\%VA،rT) ودرجة ممارسة (كبيرة). ب- بالنـسبة للنتـــائج الخاصـــة بيطاقــة الملاحظة:

جدول ( ) المتوسط والاحر اف المعياري ونسبة الممارسة للتقويم القائم على الأداء لدى المعلمين من خلا بطاقة الملاحظة

\begin{tabular}{|c|c|c|c|c|c|}
\hline الترتيب & 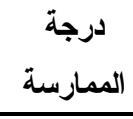 & المبارسة & المعياري & المتوسط & محاور بطاقة الملاحظة \\
\hline r & كبيرة & $\% \vee \wedge$ & - «乏AV & T,TE & صيغ التقور الأول: استخدام المعلم لبعض القائم على الأداء. \\
\hline 1 & كبيرة & \%Ar & • & r.\&7 & 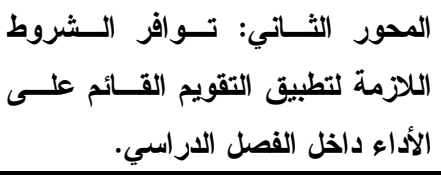 \\
\hline$r$ & متوسطة & $\% \vee \varepsilon, r T$ & . $6 \& 11$ & TGKT & الملى المعلم عند الثالث: العوامل التــى تـــؤثر \\
\hline & كبير & $\left.\% \vee \lambda_{6}\right)$ & . r ro & $r, r \leqslant r$ & الدرجة الكلية لبطاقة الملاحظة \\
\hline
\end{tabular}

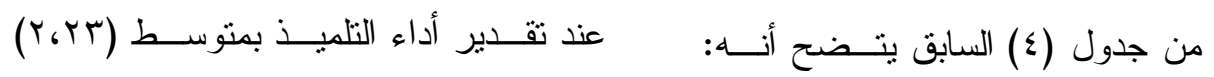

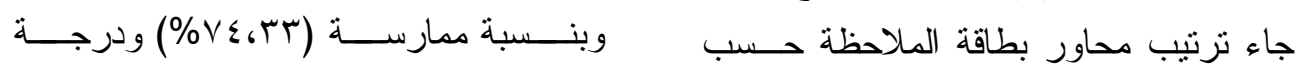

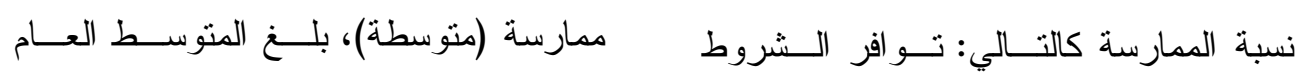

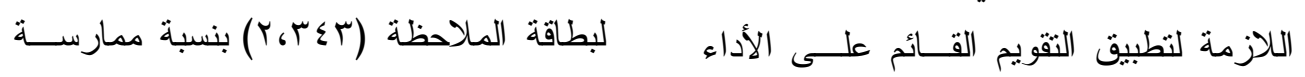

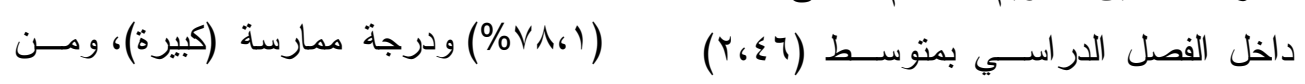

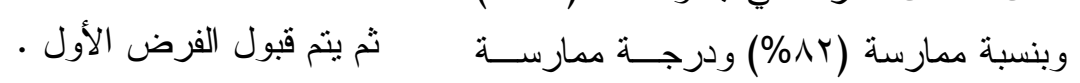

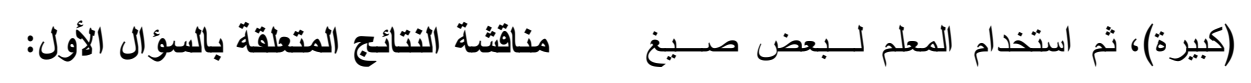

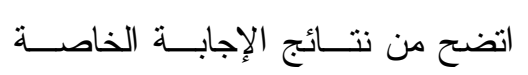

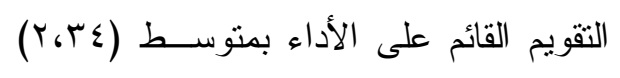

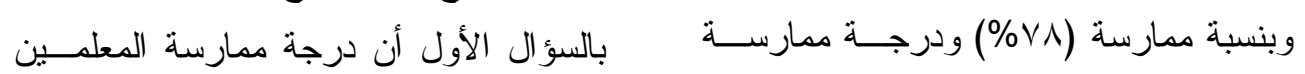

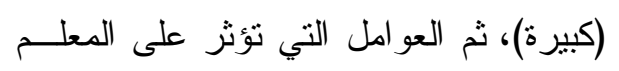


من خلال استخدام مهام مختلفة و التي تتمثنـل في الإجابات الحرة المستفيضة، و والكتابــة، و التعبير الثفوي، وعروض الإبات الأعمال لتحقيق ولنابه

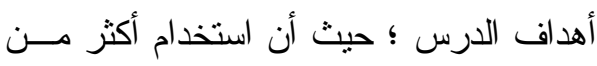

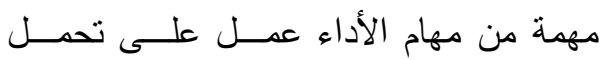

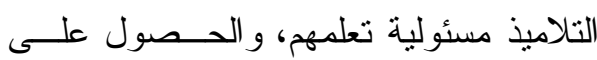
إجابات صحيحة متعددة.

وتتفق نتائج البحث الحالي مع نتــائج

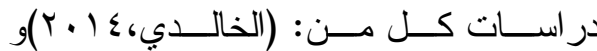

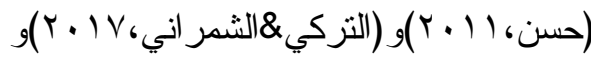

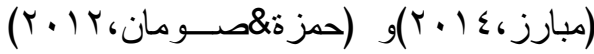
و (Firestone,etal,1998) و) و (Kim,2014) التي أسفرت نتائجها عـن المعلمين يستخدمون التقويم القائم على الأداء

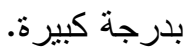
ثانياً: النتائج المتعلقة بالسؤال الثاني: للإجابة عن السؤ ال الثاني للبحث الذي نص على: "ما أثر الثقويم القائم علــى الأداء

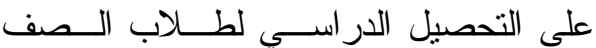
السادس الإبتدائي في مادة العلوم"، تم اختبار الفرض الثاني من فروض البحث الذي نص على: "مستوى التحصيل لدى تلاميذ معلمـي لري

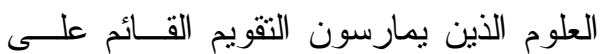

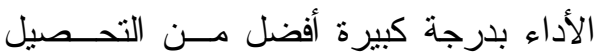
الدراسي لدى تلاميذ معلمي العلــوم الــذين

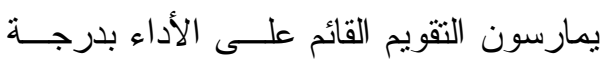

للتقويم القائم على الأداء كبيرة، وقد ترجـع هذه النتائج إلى:

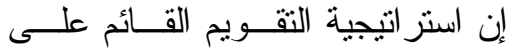

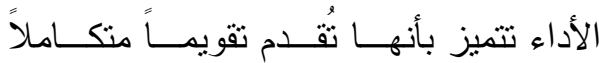

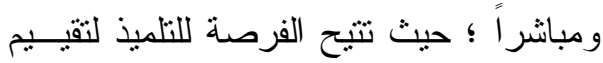
المهار ات المعرفية و الأدائية و الوجدانية التي لاني يمتلكها، كما أنها تعطــي الفرصــــة للمعلــم لاستخدام مهام حقيقية تشبه الحبــاة اليوميـــة للتلميذ لإظهار ما يمتلكه التلميذ من مهارات

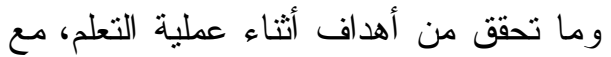

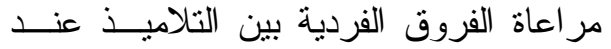
تكليفهم بتتفيذ مهمة معينة، وتـــوفير الوقـت تلت

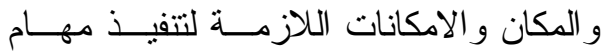
الأداء، و إمكانية تــصحيحها بحيــث يمكـن

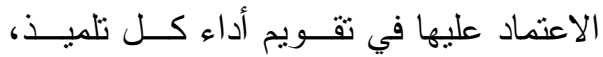
و إعطاء كلاً من المعلم و التلميذ فرصة لتعديل مهام الأداء المستخدمة بناءً علــى التغذيــة الر اجعة للوصول إلى أعلى مستويات الجودة

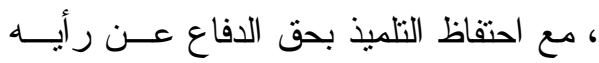
و أدائه من خلا لألدلة المنطقيـــة؛ وبالتــالي فإنها تسهم في مساعدة المعلم فـي تحقبـق تقن أهداف التعلم بفعالية؛ وهذا يجعل المعلم أكثر إقبالاً على استخدام استر اتيجية التقويم القـائم

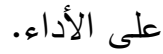
وقد كان التقويم القــائم علــى الأداء ملائماً في تقويم تعلم العلوم حيث أنه ســاعد الداء

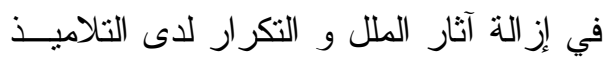


لاختبار ذلك الفرض، تــم اســتخدام الأداء بلدرجة كبيرة وتلاميذ معلمي العلـوم

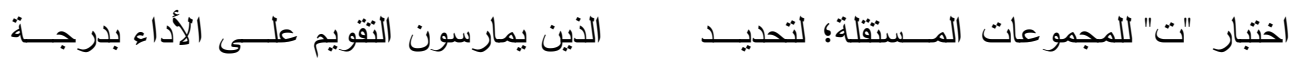

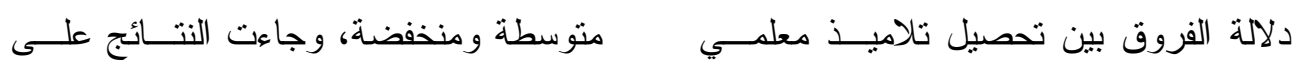

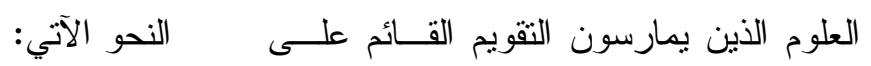
جدول (0) قيم "ت" للفروق بين مستويات تحصيل تلاميذ معلمي العلوم الأين يمارسون التقويم القائم على الأداء بدرجة كبيرة وتلاميذ معلمي العلوم الذين يمارسون التقويم

القائم على الأداء بلرجة متوسطة ومنخفضة

\begin{tabular}{|c|c|c|c|c|c|c|c|}
\hline مستوى الدلام & الحرية & قيمة & المعياري & المتوسط & ن ن & المجمو عات & مستويات \\
\hline \multirow{2}{*}{$\cdots \cdot 1$} & \multirow{2}{*}{$\varepsilon \vee \wedge$} & \multirow{2}{*}{ r.VVO } & 0.194 & rr.qV & ro. & تلاميذ معلمي العـــوم الــــين & \multirow{2}{*}{ التذكر } \\
\hline & & & $\varepsilon 6 V \leqslant 7$ & rr.VI & $r r$. & بـلارسيذ معلمي العـــوم الـــين & \\
\hline \multirow{2}{*}{.6 .1} & \multirow{2}{*}{$\varepsilon \vee \wedge$} & \multirow{2}{*}{ r.१९Y } & 7.1799 & $\left.r V_{6} r\right)$ & ro. & تلاميذ معلمي العـــوم الــــين & \multirow{2}{*}{ الفهر } \\
\hline & & & $7 . \wedge V$ & rOGT & $r r$. & بـلارسيذ معلمي العـــوم الــــين & \\
\hline \multirow[b]{2}{*}{..$\cdot 1$} & \multirow[b]{2}{*}{$\varepsilon \vee \wedge$} & \multirow[b]{2}{*}{0,107} & ¿.9YA & $\mid V_{6} V A$ & ro. & تلألاميذ معلمي العـــوم الــــين & \multirow[b]{2}{*}{ التطبيق } \\
\hline & & & $\varepsilon, T \leq \varepsilon$ & $10,0 \leqslant$ & rT. & 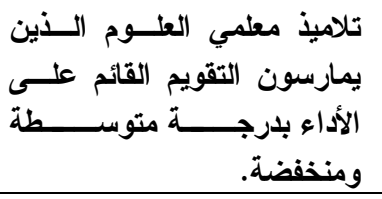 & \\
\hline \multirow[b]{2}{*}{$\cdots 1$} & \multirow[b]{2}{*}{$\varepsilon \vee \wedge$} & \multirow[b]{2}{*}{6.09} & $1 \leq .99 \leq$ & 71.97 & ro. & تلألاميذ معلمي العـــوم الــــين & \multirow{2}{*}{ اللاختبار } \\
\hline & & & $1 \pi, 9 \leq \varepsilon$ & & rr. & 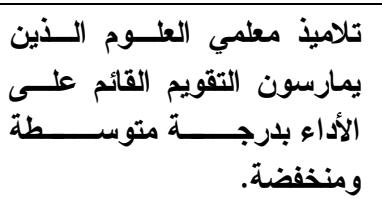 & \\
\hline
\end{tabular}


مستوى التذكر و الفهم و التطبيق؛ حيــث أن مهام الأداء المستخدمة ملازمة لعملية التعلم ؛ وذلك لأن التلميذ كوَّن إجابته بنفسه بـــلاً من أن يختار الإجابة الصحيحة من بين عدة بدائل من خلال مناقثة أسباب حدوث إصابة الصابه

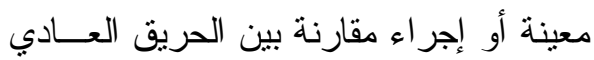

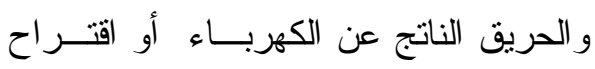
بعض الحلول لتجنب حدوث أضرار ناتجـــة

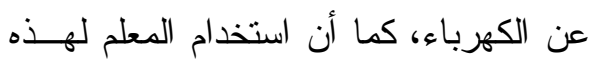

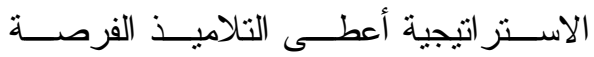
للاستفادة من خبر ات بعضهم البعض مسن

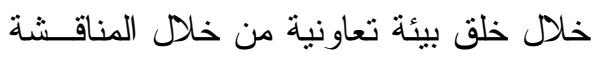
و الحوار من خلال استخدام مهــام التعبيــر

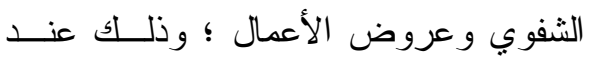
مناقثة مفهوم الصدمة الكهربية أو تــصميم نموذج يوضح التوصيل على التوالي، وجمع المعلومات من الكتاب المدرسي و المــصادر لـاني

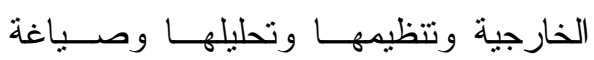
نتائجها ؛ مما ساعد على تتمية روح البحث ونث

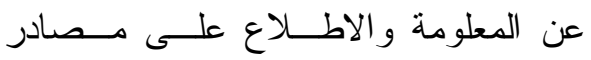
مختلفة؛ في حين أن تلاميذ معلمي العلــوم الذين يستخدمون التقويم القائم علــى الأداء بدرجة منوسطة ومنخفضة لم يــتم تـــوفير

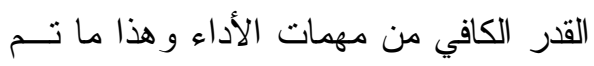
مشاهدته من خلال بطاقة الملاحظـــة فــي مهي الحصة.
من جدول(0) يتــضح أنــه: نوجــــ فروق ذات دلالة احصائية بــين مسـستويات تحصيل تلاميــذ معلمـي العلـــوم الــذين

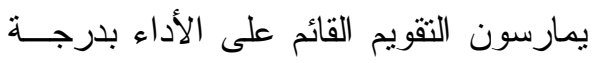
كبيرة ونتاميذ معلمي العلوم الذين يمارسون

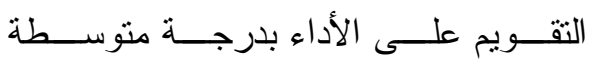

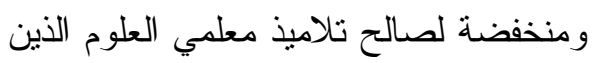

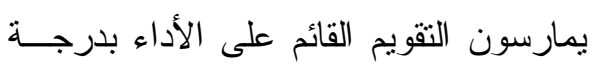

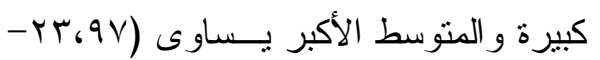
(G) -06r07-Y،99Y-Y6VV0) (ت) تساوى (ت)

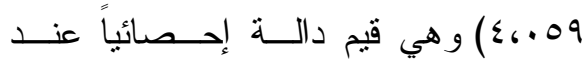

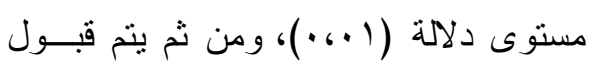
الفرض الثاني.

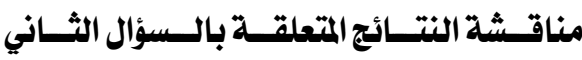

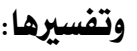

اتضح من نتائج الإجابــة الخاصـــة

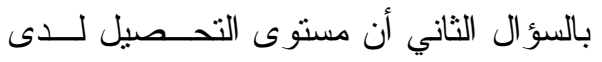
تلاميذ معلمي العلوم الذين يمارسون التقويم

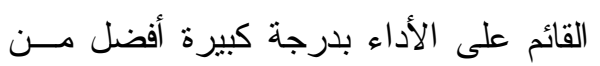
تحصيل تلاميذ معلمي العلوم الذين يمارسون

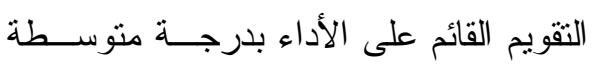

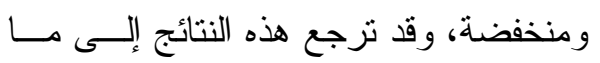
يلي: حقق تلاميذ معلمــي العلـــوم الــذين

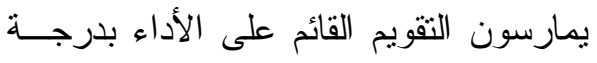

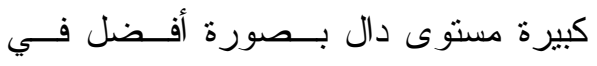




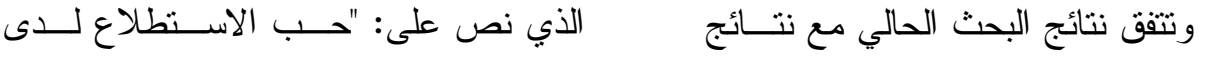

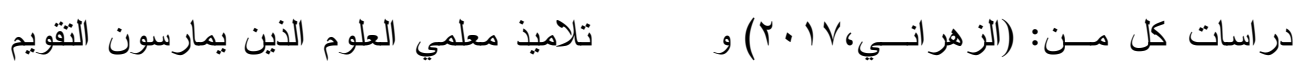

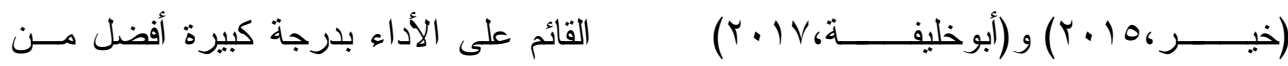

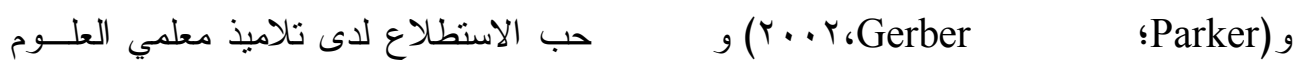

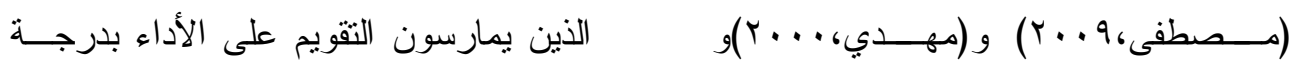

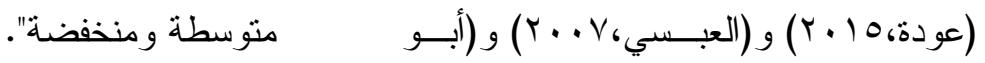

$$
\begin{aligned}
& \text { لاختبار ذللك الفرض، تــم اســتخدام }
\end{aligned}
$$

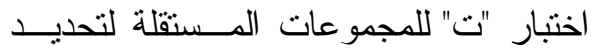

$$
\begin{aligned}
& \text { دلالة الفروق بين حــب الاســنطلاع لــدى } \\
& \text { تلاميذ معلمي العلوم الذين يمارسون التقويم } \\
& \text { بدرجة كبيرة وتلاميذ معلمي العلوم الــذين }
\end{aligned}
$$

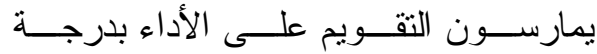

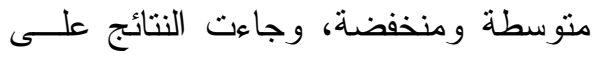

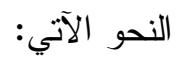

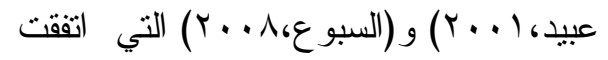

$$
\begin{aligned}
& \text { على أن التقويم القائم علــى الأداء لــــه دور } \\
& \text { إيجابي في زيادة التحصيل الدراسي. } \\
& \text { ثالثا: النتائج المتعلقة بالسؤال الثالث: } \\
& \text { للإجابة عن السؤال الثالـــث للبحـــث } \\
& \text { الذي نص على : "ما أثزر التقويم القائم على لإنى }
\end{aligned}
$$

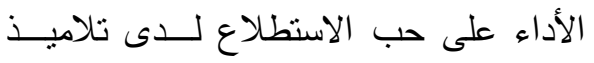

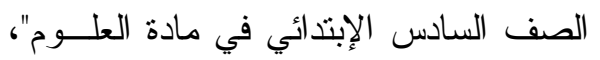

$$
\begin{aligned}
& \text { تم اختبار الفرض الثالث من فروض البحث }
\end{aligned}
$$


جدول (†)

قيم "ت" للفروق بين حب الاستطلاع تلاميذ معلمي العلوم الذين يمارسون التقويم القائم على الأداء بدرجة كبيرة وتلاميذ معلمي العلوم الذين يمارسون التقويم على الأداء بلدرجة متوسطة ومنخفضة

\begin{tabular}{|c|c|c|c|c|c|c|c|}
\hline مستوى الدلاكة & الحرية & $\begin{array}{l}\text { قيمة } \\
\end{array}$ & الالمعراف & المتوسط & $\dot{~}$ & المجموعات & أبعاد حب الاستطلاع \\
\hline \multirow[b]{2}{*}{$\cdot 6 \cdot 1$} & \multirow[b]{2}{*}{$\varepsilon \vee \wedge$} & \multirow[b]{2}{*}{ \&،ATE } & r.ITr & $\left.r r_{6}\right) r$ & ro. & تيمارسون التيذ معلمي العلوم الذين & \multirow{2}{*}{ 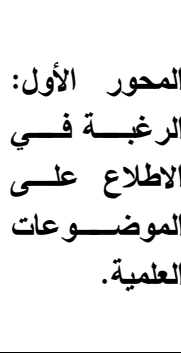 } \\
\hline & & & $0, r \cdot r$ & MI.rT & rr. & 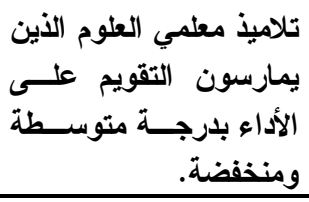 & \\
\hline \multirow[b]{2}{*}{$\cdots 1$} & \multirow[b]{2}{*}{$\varepsilon \vee \wedge$} & \multirow[b]{2}{*}{$7, \leqslant 0 \leqslant$} & $r_{6} \wedge 11$ & $196 \mathrm{KV}$ & ro. & تلاميذ معلمي العلوم الذين & \multirow{2}{*}{ 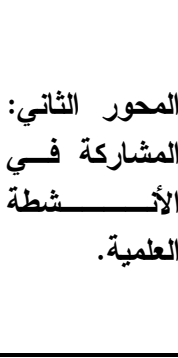 } \\
\hline & & & $\varepsilon_{6} \cdot 71$ & IVGK & rT. & 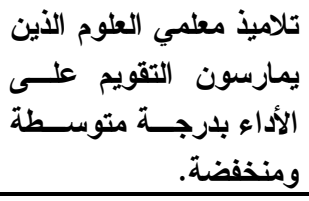 & \\
\hline \multirow[b]{2}{*}{$\cdot 6 \cdot 1$} & \multirow[b]{2}{*}{$\varepsilon \vee \wedge$} & \multirow[b]{2}{*}{ A, YTE } & r،乞Ar & $r \leq 69 r$ & ro. & كبيرة تلاميذ معلمي العلوم الأين & \multirow{2}{*}{ 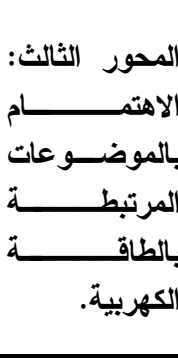 } \\
\hline & & & 0.741 & M) $6 \leqslant r$ & rr. & 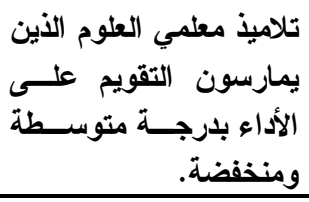 & \\
\hline \multirow[b]{2}{*}{$\cdot 6 \cdot 1$} & \multirow[b]{2}{*}{$\varepsilon \vee \wedge$} & \multirow[b]{2}{*}{$V, V 09$} & $7 . \leqslant 91$ & $T V G T Y$ & ro. & تيمارسون التقويذ معلمي العلوم الأين & \multirow{2}{*}{ للارجة الكلية } \\
\hline & & & $1 \pi_{6} 0 \leqslant 9$ & 09.199 & rr. & تلاميذ معلمي العلوم الأين & \\
\hline
\end{tabular}


وفق خطو ات مرنبة، و استخدام أكتــر مــن مهمة لتحقيق الهدف المطلوب؛ مما أدى إلى ملى ولى

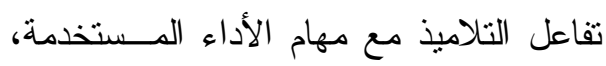

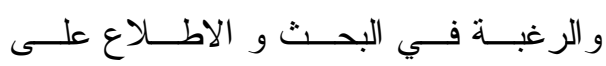

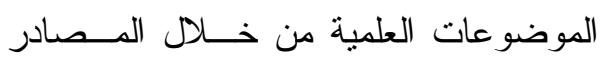
الخارجية ، و عدم اكتفاء التلاميــذ باســتقبال

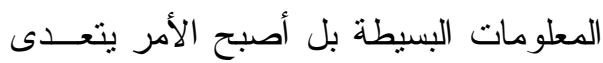
ذللك عن طريق البحث و الرغبة في اكتشاف

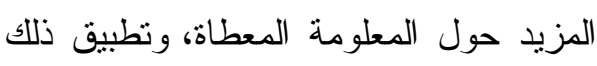
في مواقف جديدة، و الميل نحو الاكتـشـافات العلمية و البحث عن المسببات و النتائج و إيجاد الحلول و التتبؤ بما سيحدث. وقد اتصفت مهــام الأداء التــي تــم استخدامها المعلمون الذين يستخدمون التقويم

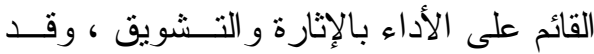

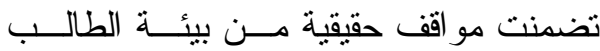
و المرتبطة بالطاقة الكهربية منل البحث عـن مون

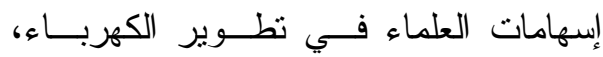
وتشجيع التلاميذ على الاطلاع على المصادر الخارجية لجمع معلومات مرتبطـــة بالطاقــــة

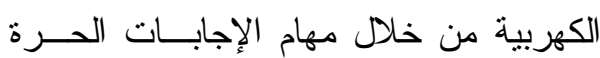

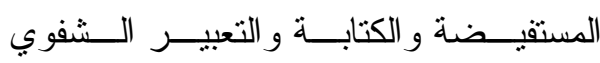

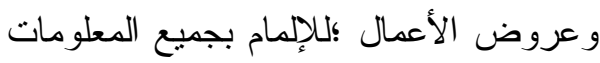
حول الطاقة الكهربية و المصباح الكهربــي؛

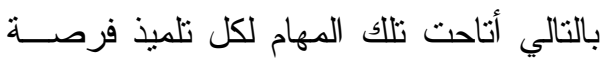

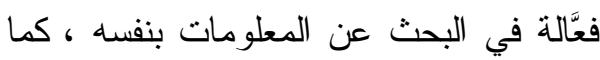
أتاحت للمعلم الفرصة للحكم على أداء التلميذ

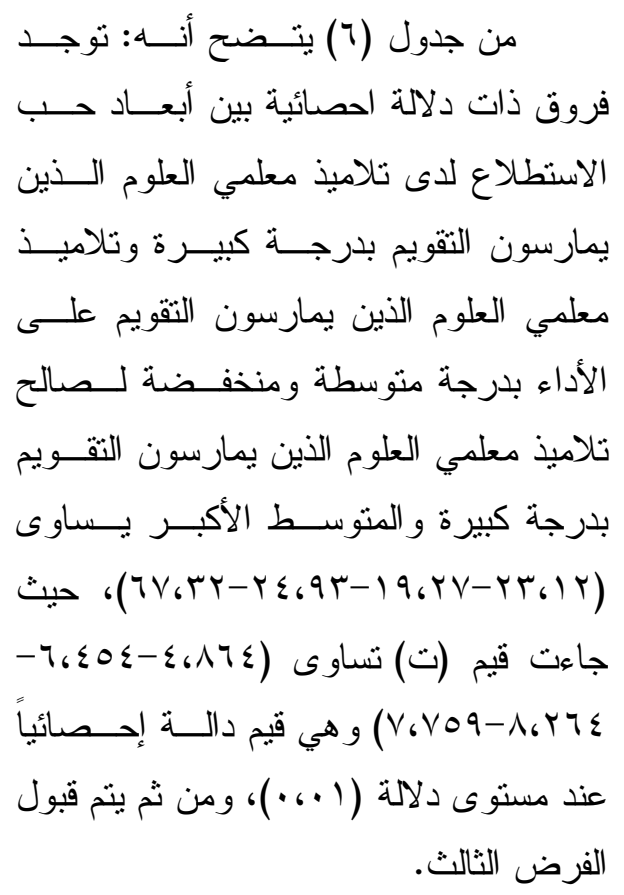
بما يتضمنه من أنشطة فعالة وأجو اء تعليمية 
قوي بين التقويم القائم على الأداء والتحصيل الدراسي لتلاميذ الصف السادس الابتــدائي،

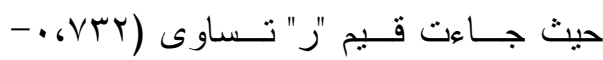

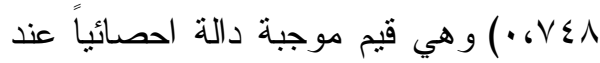

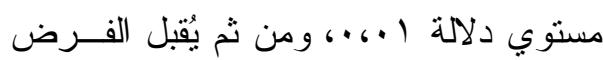

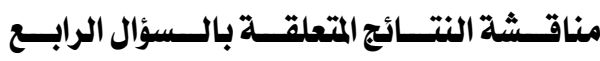
وتفسيرها:

اتضـح من نتــائج الإجابــة الخاصــة

بالسؤال الرابع وجود علاقة ارتباطية قويـــة بين التقويم القائم على الأداء و الأداء المعرفي لتلاميذ الصف السادس الابتدائي، وقد ترجع هذه النتيجة إلى:

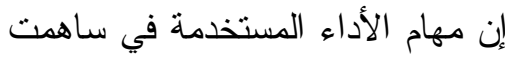

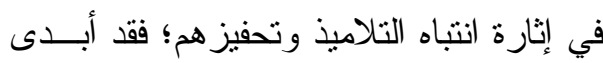

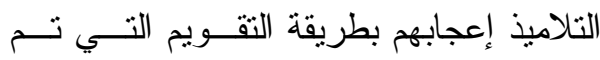

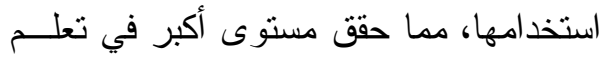

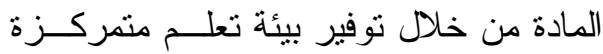

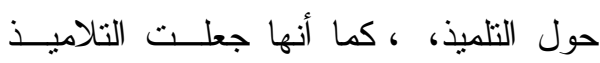

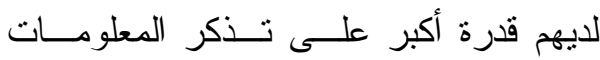

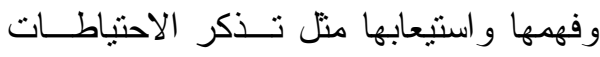
الواجب اتباعها عند التعامل مــع الكهربـــاء

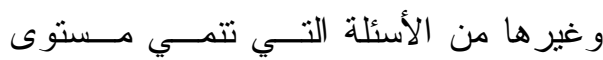

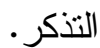
بالإضـافة إلى جعـلـل التلميــــ أكتــر إيجابية ومشاركة في تطبيق المهام المطلوبة

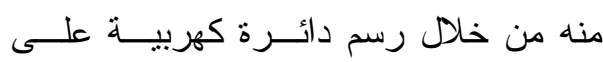

من خلال استخدام أكثر من مهمة؛ في حـين أن معلمي العلوم الذين يــستخدمون التقــويم القائم على الأداء بدرجة منوسطة ومنخفضة

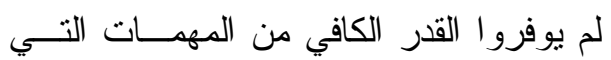
تشجع على الاطلاع و البحث . وتتفق نتيجة البحث الحالي مع نتــائج

در اســات كـلـ مــن:Stumm,2011) و (Hafenstein\&Tucker,1994) و)(Blankenship,2003) (Eren\&Coskun,2016) رابعاً: النتائج المتعلقة بالسؤال الرابع: للإجابة عن السؤال الرابـع للبحــث و الذي نص على: "إلى أي مدى توجد علاقة ارتباطية بين التقويم القائم على الأداء و الأداء المعرفي لدى تلاميذ الصف السادس الإبتدائي في مادة العلوم"، نم اختبار الفرض الرابع من لن فروض البحث و الذي نص على: توجد علاقة ارتباطية بــين التقــويم القائم على الأداء و التحصيل الدراسي لتلاميذ الصف السادس الابتدائي". لاختبار هذا الفـرض تــم اســتخدام

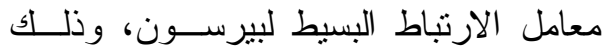

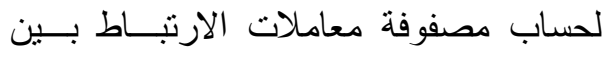
التقويم القائم على الأداء و التحصيل الدراسي الاملي

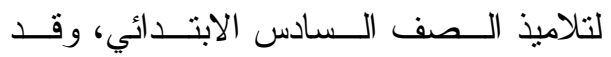
توصلت النتائج إلى أنه يوجد ارتباط طردي 
توصلت النتائج إلى أنه يوجد ارنباط طردي

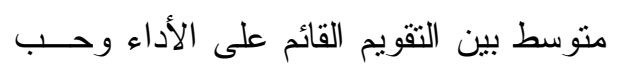
الاسنطلاع لتلاميذ الصف السادس الابتدائي،

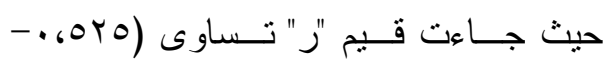
r r r • ) و هي قيم موجبة دالة احصائياً عند

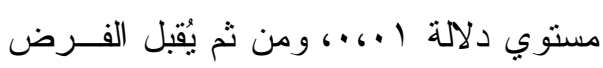

الخامس مناقشة النتائج التعلقة بالسؤال الخامس:

اتضـح من نتــائج الإجابــة الخاصـــة

بالسؤ ال الخامس أنه توجد علاقة ارتباطيــة متوسطة بين التقويم القائم على الأداء وحب الثب الاستطلاع لتلاميذ الصف السادس الابتدائي، وقد ترجع هذه النتيجة إلى ما يلي:

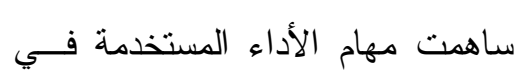

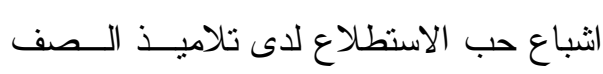

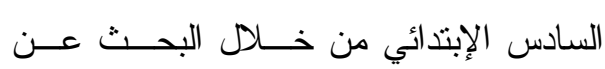

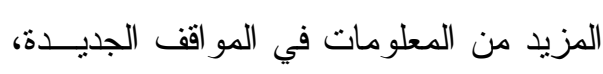

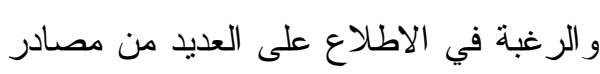

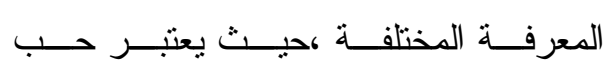

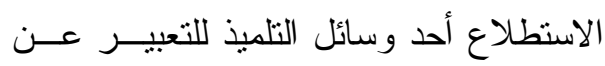

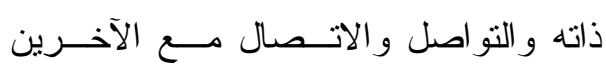
و التعبير عن آرائهم بحرية من خلال مهــام التعبير الثفوي وعروض الأعمال ،وإظهار المعلومات و المهار ات التي لديــهـ و التعبيــر عنها بحرية تامة، كما أنه أحد وسائل المعلم

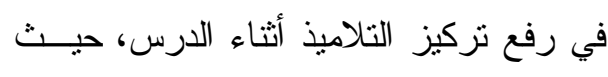
أن مهمة المعلم الحفاظ على مستوى عال من
التو الي و أخرى على التـــــ ازي مــن خـــلد المعطيات المعطاة وغير ها من الأسئلة التـي

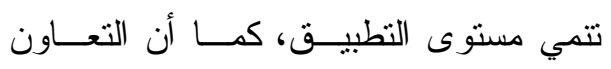
و المشاركة بين التلاميذ بعضهم البعض وبين

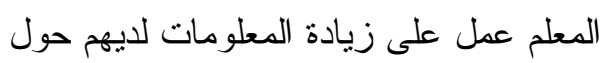

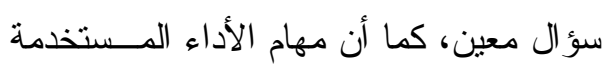

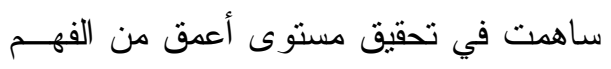

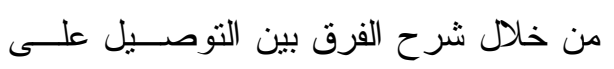
التو الي و التوصيل على التوازي وتقديم الأدلة و البر اهين ؛ مما أدى إلى زيــادة التحــــيل الدر اسي. خامساً: النتائج المتعلقة بالسؤال الخامس للبحث: للإجابة عن السؤال الخامس للبحــث

و الذي نص على: "إلى أي مدى توجد علاقة لإنة

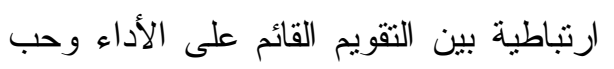

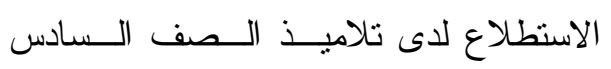

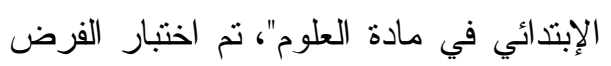

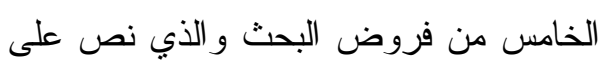

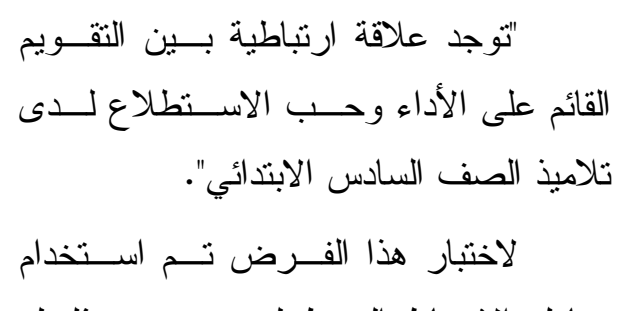

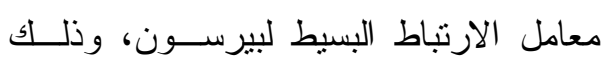

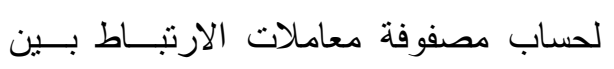

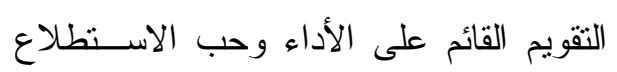

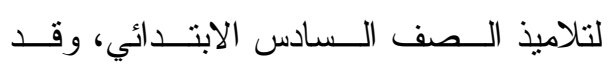


في ضوء نتائج البحث يمكن إجر اء الدر اسات المستقبلية التالية:

() دراسة مماثلة للبحث الحـالي علـى

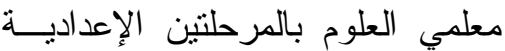

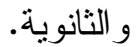

r) الكثف عن المعوقـات التــي تمنــع

استخدام استر اتيجية التقويم القائم على لع

الأداء، وكيفية التغلب عليها بالمر احل

$$
\text { الار اسية المختلفة. }
$$

r) أثر استراتيجية التقويم القـائم علــى

الأداء في تتمية مهار ات التفكير العليا لاى تلاميذ المرحلة الإعدادية.

؟) أثر استراتيجية الثقويم القـائم علـى

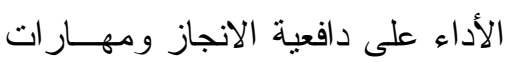

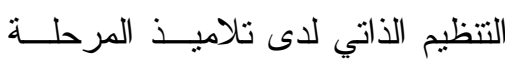

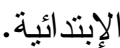

المراجع - - المع

أولاً: المراجع العربية:

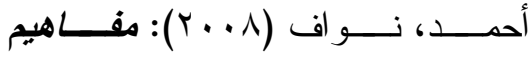

ومصطلحات في العلـــوم التربويــة ، الاردن، دار المسيرة للنشر و التوزيع.

التركى،خلود بنــت

إبـــر اهيم و الــشمر اني،ستــــيد بـــن

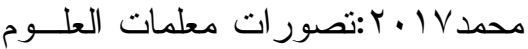

في مدينة المجمعة حول التقويم البديل،

مجلة كلية التربية (جامعسـة بنهـا) -
التزكيز من بداية الحـصة حتــى نهايتهــا؛ وبالتالي كان المعلم يركز على استخدام مهام تنمي حب الاستطلاع لاى التناميذ من خلال

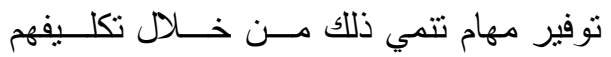
بكتابة التقارير البحثية حول موضوع دون معسين

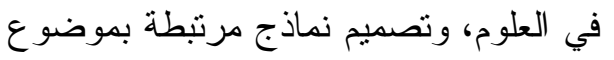

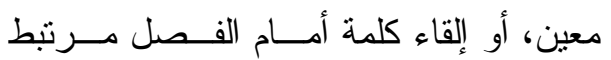
بموضوع الدرس، واستخدام أكثر من مهــــة

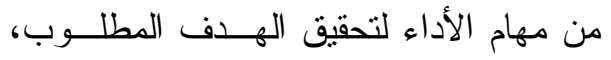
وتقديم المثيرات ، وتوفير جو مسـريح لكــل التلاميذ.

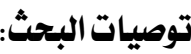

في ضوء نتائج البحث تم تقديم التوصـيات

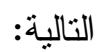

() تخفيف الأعباء التدريسية و الإثـــر افية على المعلم ؛ ليــمكن مــن متابعــة التلاميذ وتقويمهم. r

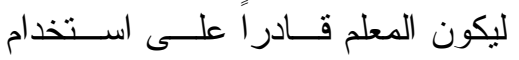
التقويم القائم على الأداء. ץ) إثر اء محتوى منهج العلوم بأســاليب التقويم لفاعليتها في تحقيق العديد من لئ لاء

$$
\text { الأهداف التربوية. }
$$

ع) توفير الإمكانات المادية والتتظيميــة

$$
\text { لتطبيق التقويم القائم على الأداء. }
$$

مقتزحات البحث: 


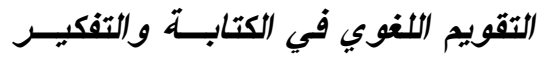

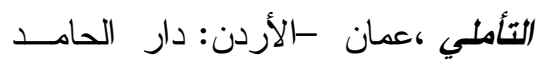

$$
\text { للنشر و التوزيع. }
$$

^) زيتون،حسن حسين و زيتون،كمال عبد

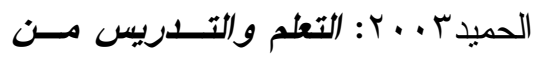

منظور النظريّة البنائية ،القاهرة ،عالم

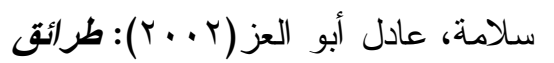

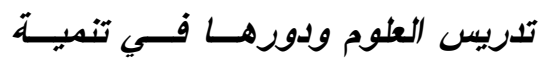

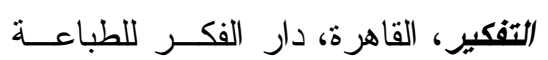

$$
\text { و النشر و التوزيع. }
$$

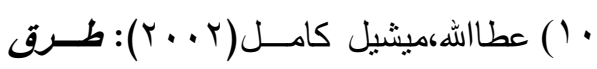
وأساليب تدريس العلوم، الطبعة الثانية،

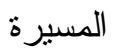

عمان:دار

$$
\text { للنشر و التوزيع و الطباعة. }
$$

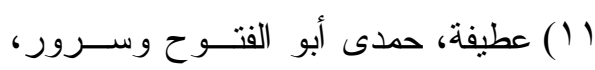

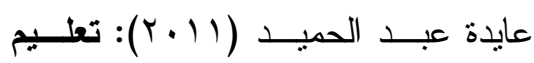

العلوم في ضوء ثثقافة الجودة: الأهداف

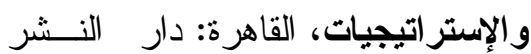

$$
\text { لامعات. }
$$

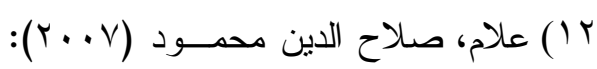

التقويم التّربوى البديل أسُسُه النظرية

والمنهجية وتطبيقاته المبيدانية، القاهرة:

$$
\text { دار الفكر العربى. }
$$

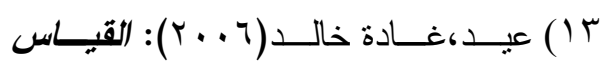

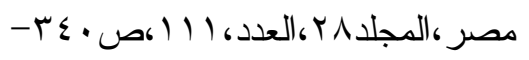

.$r V \varepsilon$

r) الخالدي،عادي بن كريم عادي(؟ (ب)

: درجة ممارسة معلمي العلوم الطبيعية

بالمرحلة المتوسطة لمهـــار ات الثقــــيم

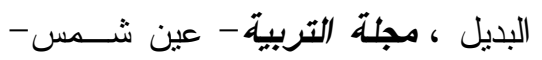

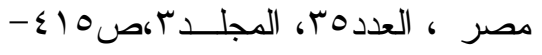
. รTT

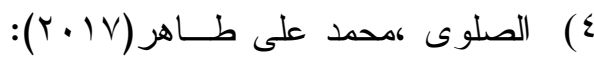

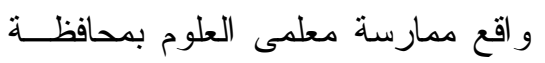

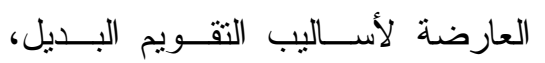

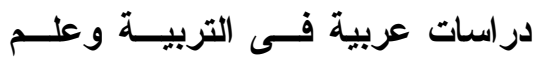

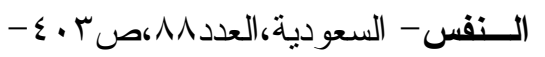

. EYr

0) اللقانى، أحمد حسين ومحمـــفارعـة

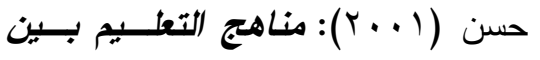

الوقاقع و والمـستقبل، القــاهرة: عــالم

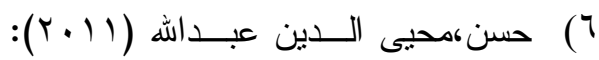

تطوير أساليب تقويم الطالبات بكليـات

التزبية وفقاً لنموذج تقويم الأداء : رؤية

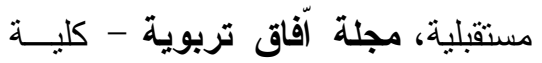
التزبية - جامعة القراّن الكريم و العلوم

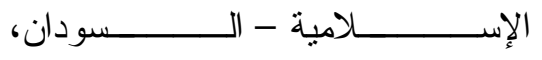
س (6) (19)

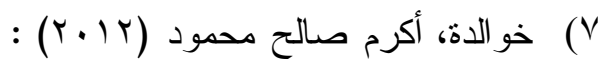


Department

Education,p(20).

19) Brindley, $\mathrm{G}$.

(1998).

Outcomes-based assessment and reporting in language learning programmes: $A$ review of the issues. Language Testing, 15(1), 45-85.

20) Harnisch, D. L. Performance-based assessment: $A$ quality improvement strategy. In Vision of Quality: How Evaluators Define, Understand and Represent Program Quality (pp. 253269). Emerald Group Publishing Limited.

21) Hill, M. E., \& McGinnis, J. (2007). The curiosity in marketing thinking. Journal of Marketing Education, 29(1), 52-62.

22) Hussey, T., \& Smith, P. (2003). The uses of learning outcomes. Teaching in higher education, 8(3), 357-368.

23) Parker, V. A., \& Gerber, B. L. (2002). Performance-based assessment, science festival exhibit presentations, and elementary science achievement. Journal of elementary science education, 14(1), 59.

$$
\text { Sوكتبة الفلاح للنشر و التوزيع. SPSS }
$$

ـ ( ) معثي،خالد بن محمد و المقحم،إبــر اهيم

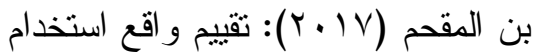

معلمي العلوم التقويم البديل في المرحلة

الإبندائية بمدينة الرياض، مجلة العلوم

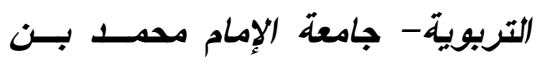

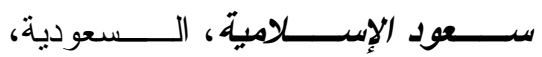

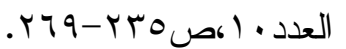

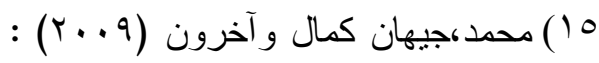

تقويم طلاب المدرسة الثانوية الفنية " ماندان

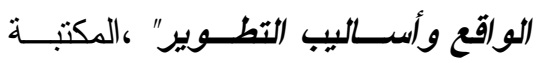

$$
\text { العصرية للنشر و التوزيع. }
$$

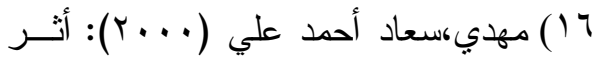

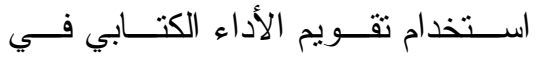

تحصيل طلاب الصف الثاني الثـانوي

في مادة الكيمياء في مدينة عدن، رسالة

ماجستير ،جامعة عدن-اليمن.

ثانياً: المراجع الأجنبية:

17) Barlowe,Avram\&Cook,Ann,(2 016): Putting the Focus on Student Engagement"The Benefits of PerformanceBased Assessment,American Educator,p(4-7).

18) Blankenship,Trent (2003) : Wyoming Early Childhood Readiness Standards, State Superintendent of Department of Education, Wyoming 


\begin{tabular}{|c|c|}
\hline $\begin{array}{l}\text { Dissertation } \\
\text { International, } 57 \quad(1) \text { : 159B } \\
\text { (UMI No 9613864). The U.S. } \\
\text { Department of Education. } \\
\text { (1993).Student Portfolios: } \\
\text { Classroom Uses. USA }>\end{array}$ & $\begin{array}{l}\text { 24) Stecher, } \text { B. (2010). } \\
\text { Performance assessment in } \\
\text { an era of standards-based } \\
\text { educational } \\
\text { accountability. Standford } \\
\text { Center for Opportunity Policy }\end{array}$ \\
\hline $\begin{array}{l}\text { 26) Harun, C. Z., \& Iqbal, M. } \\
\text { (2018). } \\
\text { Assessment of State Senior } \\
\text { High School Teachers Aged } \\
56 \quad \text { Years and } \\
\text { Above. International Journal } \\
\text { of Instruction, 11(1). }\end{array}$ & $\begin{array}{l}\text { in Education. } \\
\text { 25) Tockstein, C. (1995): An } \\
\text { Investigation of the } \\
\text { Relationship Between Students } \\
\text { Scores in Third- and Fourth } \\
\text { Grade Science Performance- } \\
\text { Based Instrument and Paper } \\
\text { and Pencil Measures, }\end{array}$ \\
\hline
\end{tabular}

